\title{
Left peripheral focus: mismatches between syntax and information structure
}

\author{
Gisbert Fanselow • Denisa Lenertová
}

Received: 16 March 2006 / Accepted: 24 November 2009 / Published online: 24 September 2010

(C) The Author(s) 2010. This article is published with open access at Springerlink.com

\begin{abstract}
In Czech, German, and many other languages, part of the semantic focus of the utterance can be moved to the left periphery of the clause. The main generalization is that only the leftmost accented part of the semantic focus can be moved. We propose that movement to the left periphery is generally triggered by an unspecific edge feature of $\mathrm{C}$ (Chomsky 2008) and its restrictions can be attributed to requirements of cyclic linearization, modifying the theory of cyclic linearization developed by Fox and Pesetsky (2005). The crucial assumption is that structural accent is a direct consequence of being linearized at merge, thus it is indirectly relevant for (locality restrictions on) movement. The absence of structural accent correlates with givenness. Given elements may later receive (topic or contrastive) accents, which accounts for fronting in multiple focus/contrastive topic constructions. Without any additional assumptions, the model can account for movement of pragmatically unmarked elements to the left periphery ('formal fronting', Frey 2005). Crucially, the analysis makes no reference at all to concepts of information structure in the syntax, in line with the claim of Chomsky (2008) that UG specifies no direct link between syntax and information structure.
\end{abstract}

Keywords Czech · German · Focus · Topic · Information structure · Intervention effects · Cyclic linearization · A-bar-movement · Prosody-syntax interface · Accentuation

G. Fanselow

Department Linguistik, Universität Potsdam, Karl-Liebknecht Str. 24-25, 14467 Potsdam, Germany e-mail: fanselow@uni-potsdam.de

D. Lenertová (凶)

Seminar für Slavische Philologie, Georg-August-Universität Göttingen, Humboldtallee 19, 37073

Göttingen, Germany

e-mail: denisa.lenertova@ phil.uni-goettingen.de 


\section{Introduction}

In Czech (Cz), German (Ge), and other languages, virtually any category can appear in the left periphery of declarative clauses, as (1) illustrates for direct objects. In the standard analysis of such sentences, the mechanics of the movement of the object is described along the lines designed for $w h$-fronting, i.e., the fronting of the object establishes an agreement relation between an operator-like feature of the object and Comp. In particular, the features relevant for movement encode notions of information structure such as 'focus' or 'topic' in such an analysis.
a. [Den Josef $]_{i}$ mag jeder $t_{i}$. the.acc Josef likes everybody.nom
b. Josefa $\mathrm{i}_{\mathrm{i}}$ (každý) uznává (každý) $\mathrm{t}_{\mathrm{i}} \cdot{ }^{1}$
Josef.acc everybody.nom appreciates everybody.nom 'Everybody appreciates Josef.'

The present paper argues that this view is misguided. Accentuation rather than informational status determines which categories can be fronted, but this special role of accentuation does not imply that syntax refers to prosodic features. Accentuation comes into play indirectly only, its relevance for fronting stems from the fact that accentuation is a side-effect of cyclic linearization in the sense of Fox and Pesetsky (2005) and Müller (2007). In addition to offering a new analysis of Czech and German constituent order, our paper therefore also addresses broader theoretical issues. First, our findings support the view (see, e.g., Chomsky 2008) that notions of information structure do not figure in the syntactic derivation, at least not in the sense of being formally responsible for movement. Second, the analysis proposes a treatment of accent-related locality constraints on movement, which is relevant for the issue of the interaction of syntax and phonology.

The paper is organized as follows. Section 2 sketches the standard analysis of movement to SpecCP in Czech and German, and presents a number of observations that call for a revision. A phenomenon we call 'subpart of focus fronting' (SFF) turns out to be particularly problematic. A detailed discussion of its properties follows in Sect. 3, leading to the main generalization that SFF allows only the leftmost accented part of the focus constituent to be placed into SpecCP. We account for its crucial properties in Sect. 4 by modifying the cyclic linearization theory of Fox and Pesetsky. The analysis is then extended to other types of movement to the left-periphery. In Sect. 5, we dismiss alternative analyses of SFF in terms of an attraction of accents, remnant movement of a focus phrase, or scattered deletion. Section 6 argues that there is no need for focus or topic movement rules in addition to the movement triggered by an unselective edge feature of $\mathrm{C}$ in German and Czech. A brief look at SFF in further languages in Sect. 7 motivates a three-way typology of languages with respect to movement to the left periphery.

\section{Previous analyses of the left periphery}

The possibility of fronting topics and foci in Czech and German suggests that syntactic movement to the left periphery may be formally driven by information structure

\footnotetext{
${ }^{1} \mathrm{Czech}$ is not a verb-second language, thus word order variation behind the fronted element is possible.
} 
features. A closer look reveals that the phenomenon of fronting is empirically much broader and cannot be adequately accounted for in terms of information structure.

\subsection{Left periphery in Czech and German}

The SVO language Czech and the SOV language German share the basic grammar of the clausal left periphery. Both languages have second position effects manifesting themselves in the (finite) verb second constraint of German main clauses, and the obligatory placement of clitics (pronominals and auxiliaries) into the second position in Czech. The position preceding the finite verb and the clitics is occupied by a wh-phrase in constituent questions, and by some maximal projection that can bear virtually any grammatical function (subject, adjunct, direct and indirect object, etc.) in declarative clauses.

For German wh-question, there is no reason to work with anything but the standard generative account. The $w h$-phrase moves to SpecCP, and the second position is filled by movement of $\mathrm{V}$ to $\mathrm{C}$.

(2) $\quad\left[\mathrm{CP}[\mathrm{Wen}]_{\mathrm{i}} \quad[\mathrm{C}\right.$ hat $]\left[\mathrm{TP}\right.$ der Peter $\mathrm{t}_{\mathrm{i}}$ eingeladen $\left.\left.\mathrm{t}_{\mathrm{V}}\right]\right]$ ? who.acc has the.nom Peter invited?

'Who has Peter invited?'

The idea suggests itself that the fronting of XPs to the left periphery of declaratives finds the same analysis (Thiersch 1978). Most generative approaches to German subscribe to this view (but see Müller 2004). One remaining issue is whether wh-phrases and non-wh-phrases target the same slot, a question answered negatively in cartographic approaches (Rizzi 1997), which split up Comp into at least four different heads. Abstracting away from such questions, den Josef appears in SpecCP in (1a), and the finite verb is placed in $\mathrm{C}$.

(3) $\quad\left[\mathrm{CP}[\text { den Josef }]_{\mathrm{i}}\left[\mathrm{C}\right.\right.$ mag] $\left[\mathrm{TP}\right.$ jeder $\left.\left.\mathrm{t}_{\mathrm{i}} \mathrm{t}_{\mathrm{V}}\right]\right]$

The analysis for Czech is similar. Toman (1999) argues that auxiliary clitics in Czech locally relate to the complementizer and are in the highest position below $\mathrm{C}^{0}$ (FinP/MoodP in his account), a similar proposal is made in Lenertová (2004). ${ }^{2}$ Meyer (2004) argues that wh-phrases, as in (4a), target SpecCP in Czech. This can be applied to fronted elements generally, as in (4b).
a. $\left[\mathrm{CP}[\mathrm{Koho}]_{\mathrm{i}}\left[\mathrm{FinP}\left[\right.\right.\right.$ Fin by] Petr pozval $\left.\left.\mathrm{t}_{\mathrm{i}}\right]\right]$ ? who.acc aux.cond Peter invited.sg.ms
'Whom would Peter invite?'
b. [CP [Josefa $]_{i}[$ FinP [Fin by] (každý) uznával Josef.acc aux.cond everybody appreciated.sg.ms

\footnotetext{
${ }^{2}$ See also Kučerová (2005). In contrast to the V2-phenomenon in Germanic, there is no complementary distribution of second position clitics and complementizers in Slavic. Clitic auxiliaries follow the complementizer in embedded clauses; see Franks and King (2000) for discussion.
} 
$W h$-movement to SpecCP is linked to the $w h$-criterion, requiring that a $[+w h]$ C agrees with a [+wh]-phrase in its specifier, and vice versa (Rizzi 1991). The apparent parallelism between $w h$-movement and the movement to the left periphery in declaratives suggests that the latter is also licensed by establishing an agree relation between C(-heads) and the fronted XP (Rizzi 1997). It is natural to link this agree relation to the information structure function of non-subject movement to SpecCP (e.g., Grewendorf 1980). In (5), for example, the fronted elements are interpretable as topics (e.g., Reinhart 1981). The fronting in (5) might establish agreement for a [+topic] feature.
a. Den Bürgermeister hat wohl
der Villenbesitzer angezeigt. (Ge) the.acc mayor has supposedly the owner-of-villa reported
b. Starostu prý udal majitel vily. mayor.acc supposedly reported owner.nom villa.gen
'The owner of the villa supposedly reported the mayor.'

Focused phrases can also move to the left periphery, as in $(6 \mathrm{a} \& \mathrm{c})$. The fronting is optional, cf.(6b\&d) with focus in situ in the same context. Following the common practice, we identify the semantic focus of an utterance by the wh-phrase in a congruent constituent question. ${ }^{3}$ In (6) it is the DP corresponding to what. ${ }^{4}$

$(6)^{5} \quad$ What did you see there?

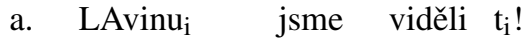 avalanche.acc aux.1pl seen.pl
b. Viděli jsme LAvinu!
c. [Eine LaWIne $]_{i}$ haben wir $t_{i}$ gesehen! an avalanche have we seen
d. Wir haben eine LaWIne gesehen! 'We saw an avalanche!'

The term 'topicalization' sometimes used in the context of movement to SpecCP is thus a misnomer. In order to avoid confusion, we will use the term 'left periphery movement' (LP-movement) for movement to SpecCP in declaratives.

The data in (5-6) are compatible with several models concerning the syntactic encoding of information structure. Comp may optionally possess a focus or a topic feature with which the fronted phrases agrees, and Comp may be split into independent Topic and Focus heads, which attract XPs with the corresponding informational value (Rizzi 1997).

\footnotetext{
${ }^{3}$ Depending on the context, the semantic focus may include given (unaccented) elements. Crucially, the constituent corresponding to the semantic focus must contain the main prominence of the clause. See Büring (2006, 2007); Schwarzschild (1999), and Reich (2003: Chap. 2), among others, for discussion.

${ }^{4} \mathrm{DP}$-focus is also referred to as 'narrow' and VP/IP-focus as 'wide' focus throughout the paper. Note that this terminology is only descriptive and is not meant to correlate with distinctions like 'informational' vs. 'contrastive' focus (Kiss 1998). The latter distinction is orthogonal to the discussion of focus in this paper.

${ }^{5}$ In the Czech and German examples, syllables carrying the nuclear accent will be capitalized. In relevant cases, small caps will mark syllables with prenuclear accent. In the interest of space, word order variations will lack glosses and context questions will be given in English only.
} 


\subsection{Problems of information structure driven movement}

For several reasons, however, LP-movement cannot be successfully captured in terms of information structure driven movement. First, such accounts seem problematic from a minimalist point of view. The use of focus/topic features in the syntactic derivation violates the inclusiveness condition (Chomsky 1995), according to which only those features can figure in syntactic computations that represent properties of lexical items. On obvious grounds, being a focus or a topic is not a lexical propertywords and phrases can be classified as such only when used in a specific context (see Neeleman and Szendrői 2004 and den Dikken 2006 for pertinent discussion).

LP-movement and wh-movement also differ in a number of important respects. These differences militate against equating the two processes quite independently of specific theoretical background assumptions. For instance, the locality constraints are different: LP-movement of arguments is clause-bound in many dialects of German, while wh-movement is not (Kvam 1983: 81). Likewise, wh-movement is subject to standard conditions on pied-piping, while LP-movement is not (see Horvath 2007 and Sect. 6). Furthermore, wh-movement is obligatory in Czech and German, while topic and focus fronting to SpecCP are optional, cf.(6b\&d). More importantly, $w h$-movement rarely applies optionally in the world's languages, while the optional nature of focus or topic fronting is the rule rather than the exception. Where focus fronting seems obligatory - as in Hungarian — it goes hand in hand with additional semantic properties such as exhaustivity (Kiss 1998). Arguably, this semantic property rather than focality is responsible for the obligatoriness of movement (Horvath 2007). Moreover, the island and binding data discussed by Rooth (1996) and Alboiu (2004) imply that there is no covert focus movement equivalent to covert $w h$-movement. ${ }^{6}$ If the overt movement of focus phrases was driven by a focus feature in the same way as $w h$-features drive $w h$-movement, we would be left without an explanation for the fact that one kind of movement has a covert counterpart, while the other one does not.

Finally, the analysis of LP-movement in terms of information structure features turns out to be empirically inadequate. Topics and foci are fronted in only a subset of the LP-movement contexts. When neither the focus nor the topic moves to first position (because their left peripheral placement is optional), some elements may go there in the absence of any discourse motivation. This holds, for instance, for sentential adverbs, as in (7), and for subjects, as in (8). The movement of these elements cannot serve the checking of topic/focus features.

a. Wahrscheinlich hat ein Kind einen HAsen gefangen. probably has a child a.acc rabbit caught

b. Asi si nějaké/jedno dítě chytilo ZAjíce. probably refl. a/some child.nt caught.sg.nt rabbit.acc 'A child has probably caught a rabbit.'

a. Ein Kind hat einen HAsen gefangen.

a child has a.acc rabbit caught

\footnotetext{
${ }^{6}$ See Reich (2003) and Horvath (2007) for recent arguments against island-sensitivity of focus, and Krifka (2006) and Wagner (2006) for recent arguments in favour of LF focus movement.
} 
b. Nějaké/Jedno dítě si chytilo ZAjíce. a/some child.nt refl. caught.sg.nt rabbit.acc

'A child has caught a rabbit.'

The import of such examples was first noted by Travis (1984), who argued for a TP-analysis of (8). Van Craenenbroek and Haegeman (2007) show, however, that subject-initial verb second clauses cannot be analysed as TPs. Based on a suggestion of H. Haider, Fanselow (2002) and Frey (2005) argue that (7-8) illustrate the same phenomenon: any category that can appear leftmost in TP can move to SpecCP without possessing any special discourse marking. ${ }^{7}$ We follow Frey (2005) in calling this movement 'formal fronting' (FF), but the label is just a shorthand for a particular constellation arising from the application of LP-movement, and not a name for a separate syntactic process. As we will see below (Sect. 4.3.2), FF constructions are less restricted than envisaged by Fanselow and Frey, and they can place scrambled objects into SpecCP.

While FF-constructions have figured in the discussion of LP-movement since Travis (1984), there is a further, less known set of data that also defies an analysis in terms of focus/topic fronting, cf. (9).

What did you do?, What's new?/What happened?

a. [Einen HAsen $]_{\mathrm{i}}$ habe ich $\mathrm{t}_{\mathrm{i}}$ gefangen.

a.acc rabbit have I caught

b. [Einen HAsen $]_{i}$ hat wer $t_{i}$ gefangen.

a.acc rabbit has someone caught

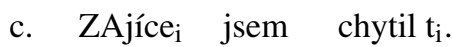

rabbit.acc aux.1sg caught.sg.ms

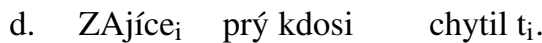

rabbit.acc prt. somebody caught.sg.ms

'I/somebody caught a rabbit.'

The context questions What did you do? and What's new/what happened? invoke VP- and IP-focus, respectively. Consequently, the fronted elements in (9) are not the semantic focus of the utterance. What is fronted is part of the semantic focus, hence we call the phenomenon subpart of focus fronting (SFF). ${ }^{8}$

(9) constitutes a further mystery for the standard theory of LP movement. How can the fronting of just some part of the focus fulfil an agreement requirement for a focus feature? Remnant movement and scattered deletion cannot solve the problem, as we shall see in Sect. 5. Data such as (9) corroborate the view that the left periphery is not confined to topics and foci in Czech and German, and that movement to SpecCP is not triggered or licensed by features related to information structure.

\footnotetext{
${ }^{7}$ See also Müller (2004) for a related account. In a split CP approach, the FINiteness head accepting pragmatically unmarked specifiers might capture the data.

${ }^{8}$ The data have received a marginal attention for German, as a problem for the theory of focus projection (Höhle 1979: 428-429, Jacobs 1991: 9) or for the nuclear stress assignment (Zubizarreta 1998: 62), but see also Krifka (1994: 145-146) and Büring (1997: 46, 72). Fanselow (2004) for German and Lenertová and Junghanns (2007) for Czech consider the phenomenon in more detail, however, they do not discuss the full scope of the data.
} 


\section{Subpart of focus movement}

FF and SFF phenomena establish that LP-movement is not confined to topics and foci. If this follows from the fact that LP-movement is triggered by an unspecific edge feature of $\mathrm{C}$ in the sense of Chomsky (2008), one needs to show that the few constraints on LP-movement that exist can be derived without recourse to information structure.

SFF will be our main emphasis in this paper. After a short discussion of its scope, we argue that SFF cannot be successfully explained away by postulating another pragmatic feature being borne by the fronted element (3.1). Then we show that SFF is subject to locality restrictions based on accentuation (3.2) and finally we argue that, despite this property, SFF is a syntactic movement (3.3).

First, it is important to note that the scope of the phenomenon goes beyond VPand IP-focus illustrated in (9) above and in (10-11). ${ }^{9}$ The context question (12a), imposing DP-focus on possible answers, is not only compatible with (13b\&d) but also with with $(13 \mathrm{a} \& \mathrm{c}) .{ }^{10}$ Only a part of the DP is fronted here, with the determiner being stranded. The answers in (13) are also congruent with the context question in $(12 b)$.

What did he do?

a. $\quad[\text { Ein BILD }]_{i}$ hat er $t_{i}$ zerrissen.

$(\mathrm{Ge})$

a picture has he torn

'He tore a picture.'

(11) What happened?

a. [Im GRAben $]_{i}$ ist er $t_{i}$ gelandet!

in ditch has he landed

'He drove into the ditch!'
a. What have you bought?
b. What have you done?/What's new?
a. BÜcher ${ }_{i}$ hab' ich mir ['npaar $t_{i}$ ] gekauft. ${ }^{11}$
books have I refl. a-few bought
'I have bought a couple of books.
b. ['Npaar BÜcher $]_{i}$ hab' ich mir $t_{i}$ gekauft.
c. KNÍžek $k_{i}$ jsem si [pár $\mathrm{t}_{\mathrm{i}}$ ] koupil.
books.gen aux.1sg refl. a-few bought.sg.ms
d. [Pár KNÍžek] jsem si t koupil.

\footnotetext{
${ }^{9}$ Jacobs (1991: 9), quoting Susanne Uhmann (p.c.), speculates that such constructions are restricted to "cases in which the verb denotes one of the prototypical actions involving the object (like reading, in the case of books)". Felicitous examples such as (10) that can be easily found in authentic sources both in German and in Czech speak against this view.

${ }^{10}$ The traces only indicate the base-position of the moved element. We leave it aside how the derivation proceeds, e.g., whether the fronted phrase undergoes remnant movement, in which case the bracketing would be different. The same concerns examples (16a\&c), (18), and (19) below.

${ }^{11}$ See also Puig-Waldmüller (2006) for similar observations.
} 
Thus, a complex picture of the interaction between semantic focus and movement emerges. With both context questions in (12), the displaced category in (13a\&c) is smaller than the semantic focus. Even when the whole DP is fronted, as in (13b\&d), the displaced category is smaller than the semantic focus in the context (12b). The fronted category is identical with the semantic focus only in the case of (13b\&d) in the context of (12a). Only this constellation could be analyzed as attraction of a focus feature.

SFF is equally possible in multiple focus structures, where one focus operator takes scope over another and the utterances have a rise-fall intonation. This kind of constellation is illustrated in (14). ${ }^{12}$
a. Are they anarchists?
HÄUser $r_{i}$ hat von denen KEIner $t_{i}$ angezündet.
houses has of these nobody set-on-fire
'No one of them has set houses on fire.'
b. Is he religious?
[Die BIbel $]_{i}$ hat er noch NIE $t_{i}$ gelesen.
the bible has he yet never read
'He has not ever read the bible.'
c. BIbli $_{\mathrm{i}}$ teda rozhodně NEčte $\mathrm{t}_{\mathrm{i}}$.
bible particle definitely not-read. $3 \mathrm{sg}$
'He definitely does not read the bible.'

We follow Reich (2003: 173-187) and van Hoof (2003) and attribute the rise on the fronted phrase to contrastive focus. Importantly, the whole predicate ('reading the bible', 'setting houses on fire', etc.) is contrasted in (14). The fronted phrase thus constitutes only a part of the comparable alternative.

(15) is a case parallel to (13), only in a multiple focus structure. The contexts (15a) and (15b) evoke a set of contrasted DPs and VPs, respectively. (16a\&c) with only a part of the DP fronted is congruent with both (15a) and (15b). So is (16b\&d), which represents an SFF case only in the context of (15b).

a. A: What have you managed to buy? B: I bought a computer, but ...

b. A: What have you managed to do? B: I visited the museum, but ...

a. BÜcher ${ }_{i}$ hab' ich AUCH ['npaar $t_{i}$ ] gekauft.

books have I also a-few bought

$(\mathrm{Ge})$

b. ['Npaar BÜcher $]_{i}$ hab' ich AUCH ti gekauft.

c. KNížek $\mathrm{K}_{\mathrm{i}}$ jsem TAKY [pár $\mathrm{t}_{\mathrm{i}}$ ] koupil.

books.gen aux.1sg also a-few bought.sg.ms

'I have also bought a couple of books.'

d. [Pár KNÍžek] jisem TAKY t koupil.

Contrastive topics in pair-list/distributive contexts, as in (17), are often analysed as contrastive focus with additional topic interpretation (see Reich 2003: 173-187; van

\footnotetext{
${ }^{12}$ Although referring to fronting in examples like (14a\&b) as I-Topicalization, Jacobs (1996: 8) notes that the fronted phrases differ from topics as they need not be referential expressions. Büring (1997: 72) proposes for cases similar to (14a\&b) that the entire VP is Topic and the fronted object is the Topic exponent.
} 
Hoof 2003). Cases like (18), where a subpart of such a contrastive topic has been fronted, can thus be subsumed under SFF.

What did Hans and Mary wear (at the wedding)?

$[\text { HANS }]_{\mathrm{T}, \mathrm{F} 1}$ hat $[\text { seinen ANzug }]_{\mathrm{F} 2}$ getragen. $\quad$ (Ge, Reich 2003: 185)

Hans has his suit worn

'Hans wore his suit.'

(18) Who gathered some information on the issue and who the visual material?

INFORMATIONEN $\mathrm{i}_{\mathrm{i}}$ hat JAN ['npaar $\mathrm{t}_{\mathrm{i}}$ ] besorgt und das

$(\mathrm{Ge})$

information has Jan a-few gathered and the

BILDMATERIAL OLI.

visualmaterial Oli

'Jan gathered some information and Oli the visual material.'

(19) Has anybody gathered some information on the new case?

$\mathrm{Ja}$, Informationen $\mathrm{i}_{\mathrm{i}}$ wurden ['npaar $\mathrm{t}_{\mathrm{i}}$ ] schon besorgt ...

yes information was a-few already gathered

'Yes, some information has been gathered (and is just being analysed).'

Nevertheless, (19) presents a context where the fronted phrase is a subpart of a noncontrastive topic, which means that the phenomenon is not limited to focus. Keeping this in mind, we will first continue in the investigation of SFF cases, before we propose a unified analysis of LP-movement in Sect. 4.

\subsection{Pragmatic properties of SFF}

In an SFF construction, the element in SpecCP is not the semantic focus and therefore cannot agree with $\mathrm{C}$ for a focus feature. In order to maintain the idea that movement to SpecCP is licensed by discourse features, one would have to make an $a d$ ditional information-structural property responsible for the SFF. For instance, one could analyse the preposed XP as a 'topic in a focus', or assume that particular 'salience' is attributed to the left-peripheral part of the focus. In general, such suggestions are not helpful, however. The non-specific indefinite ein Buch 'a book' in (20) is neither a likely candidate for an aboutness topic, nor for a contrastive topic. Furthermore, no particular salience is attributed to 'a book' (while 'book-reading' may be particularly focused or contrasted).

$$
\begin{aligned}
& \text { What do you want to do in your holiday? } \\
& {[\text { Ein BUCH }]_{i} \text { würde ich gerne } \mathrm{t}_{\mathrm{i}} \text { lesen. }} \\
& \text { a book would I eagerly read } \\
& \text { 'I would like to read a book.' }
\end{aligned}
$$

SFF constructions also cannot be explained away if we try to identify the additional pragmatic property not with respect to the preceding text (as notions such as topic and focus do) but with respect to possible effects of the fronting on the following text, such as preparing a topic shift (for such a perspective, see the Centering Theory of Walker et al. 1998). In a dialogue such as (21), the fronted non-specific DP is neither a backward looking topic or the focus of the utterance, nor does it fulfil any 
function for the following text. Nevertheless, the sentence with the fronted DP is perfectly well-formed in this context. ${ }^{13}$

What had you wanted to do in your holiday?

$[\text { Ein } \mathrm{BUCH}]_{\mathrm{i}}$ hätte ich gerne $\mathrm{t}_{\mathrm{i}}$ gelesen ...

a book had I eagerly read

aber ich musste immer Windeln wechseln, dann besuchte uns der Onkel...

'I had wanted to read some book, but I always had to change diapers, then my uncle visited us...'

A second argument against the idea that the left peripheral element in an SFF construction bears a pragmatic function of its own can be derived from the fact that, by their very nature, concepts such as topic, focus, salience, etc. are applicable only to elements with semantic content. Idioms bear interpretation only as a whole, nevertheless, they can be split by SFF, as illustrated for simple focus in (22), and for multiple focus in (23) ((23a) is taken from Jacobs 1996: 8). ${ }^{14}$ Since the moved element in such cases is meaningless, it cannot be a topic, a focus, or be particularly salient. The examples refute the idea that SFF movement is triggered by a pragmatic property of the moved item in a direct way.

Why did you quarrel with him?

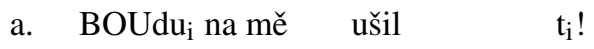

hut.acc at me.acc stitched.sg.ms

'He has cheated me!'

b. [Den GARaus $]_{i}$ hat er ihr $t_{i}$ gemacht. the garaus has he her.dat made

'He killed her.'

(23) How will Grass react to the bad reviews?

a. Nun, [die HAAre $]_{i}$ wird er sich NICHT gerade $t_{i}$ raufen.

well the hair will he himself not really pull-out

'Well, he won't be completely upset (but he will be a bit angry).'

b. [V sedmém NEbi $]_{i}$ se asi zrovna vznášet ${ }_{k}$

in seventh heaven refl. probably really float.inf

NEbude $t_{k} t_{i}$.

not-will.3sg

'Well, he won't be probably happy (but he will cope with it).'

\footnotetext{
${ }^{13}$ Examples (14b\&c) above invite an alternative interpretation in terms of a topic standing in a POSETrelation (see Walker et al. 1998) to elements introduced in the preceding discourse. Talking about religion makes priests, bibles, and the like, prominent. This alternative is less convincing for (14a) and excluded in the case of idiomatic expressions to be discussed below.

${ }^{14}$ Frey (2005) points out that some idioms have a quasi-compositional structure (Nunberg et al. 1994) relative to which parts of idioms could have an informational value of their own. However, Horn (2003) has shown that thematically non-compositional idioms are transparent for movement in German as well.
} 
We conclude that it is not plausible to postulate an additional pragmatic feature associated with the fronted element in SFF constructions. ${ }^{15}$

\subsection{Formal aspects of SFF}

The most remarkable property of SFF is a locality restriction concerning accentuation: it is always the leftmost accented XP that undergoes SFF movement, this element cannot cross another accented element. The restriction comes out clearly in idioms that involve (at least) two phrasal parts, such as (24). Only the leftmost accented XP may be fronted in such constellations, as observed by Müller (2003). Compare (24b) and (24c): fronting of the lower accented element in (24c) leads to the loss of the idiomatic reading; in contrast, the leftmost accented element in (24b) does not cross accented material and SFF is felicitous. ${ }^{16}$

What happened?/What did he do?

a. Er hat die FLInte ins KORN geworfen.

he has the gun into-the grain thrown

'He has given up.'

b. [Die FLInte $]_{i}$ hat er $t_{i}$ ins KORN geworfen. ${ }^{17}$

c. \#[Ins KORN $]_{i}$ hat er die Flinte $t_{i}$ geworfen.

Note that the 'primary' (nuclear) accent of the clause goes to the second rather than the first accented DP/PP in cases like (24a) (see, e.g., Truckenbrodt 2007 and the references there), i.e., the right PP is the 'focus exponent'. (24) thus also shows that SFF does not necessarily affect focus exponents (in contrast to claims of Fanselow 2004 and Lenertová and Junghanns 2007, a point also made by Frey 2005). SFF may target any focus subpart (that can undergo syntactic movement) as long as it crosses no other accented category.

\footnotetext{
${ }^{15}$ Native speakers sometimes characterize SFF constructions as being more 'emphatic' than their narrow focus counterparts, but this emphasis affects the predicate as a whole and never the fronted part of the predicate alone. SFF constructions may come along with specific pragmatic functions, but these do not pertain to the fronted element, but the category the fronted element was extracted from. Controlled experiments with written (see Fanselow et al. 2008 for $\mathrm{Cz}$ and Ge) and auditory (see Féry and Drenhaus 2008 for Ge) material reveal that the difference between narrow and wide focus interpretation has no influence on the acceptability of object initial sentences.

${ }^{16}$ A Google web search for the idiom die Flinte ins Korn werfen 'to give up' revealed 5 examples of the form (i), but no examples with ins Korn moved across die Flinte. We never observed any examples with crossing movement with three other idioms of the same structure.

(i) Die FLINte hat Schumacher jedenfalls noch NICHT ins Korn geworfen. the gun has Schumacher in-any-event yet not into-the grain thrown 'In any event, Schumacher has not yet given up.'

${ }^{17}$ Some speakers find the b-version of (24) less acceptable than the neutral a-version. However, they accept the idiomatic reading of this version. As a reviewer points out, some speakers do not accept an idiomatic interpretation in SFF constructions equally well for different idioms. The difference may be related to the 'transparency' of the idiom, but as remarked in footnote 14, this does not characterize the splitting potential of German idioms in general (Horn 2003).
} 
Selkirk (1995) and Kratzer and Selkirk (2007) argue that accents are obligatorily distributed on all arguments that are not discourse given (for supporting experimental evidence on German, see Truckenbrodt 2004 and Féry and Kügler 2008). Transitive verbs in wide focus constructions, on the other hand, are unaccented (see also Jacobs 1999; Wagner 2005, among others). ${ }^{18}$ Thus we expect accented higher arguments to block SFF of lower arguments in wide focus domains. On the other hand, we do not expect verbs to block SFF of objects even when they precede them as is the case in Czech. ${ }^{19}$

The above SFF examples with simple focus are in line with these expectations. They involve crossed arguments in the form of unstressed or silent pronouns, as in (25a). In contrast, (25b) is not felicitous in the wide focus context of (25). ${ }^{20}$ It contains a subject that cannot be prosodically weak in this context. On the other hand, (25b) is congruent with context questions like What did mother cook? or What's new with mother?, rendering the subject given. The subject may be unaccented and does not intervene with fronting of lower accented elements.

What's new?

a. GUlášs jsem uvařila $t_{i}$.

goulash aux.1sg cooked.sg.fm

'I cooked goulash.'

b. \#GUláši matka uvařila $t_{i}$.

goulash mother cooked.sg.fm

c. Matka uvařila GUlášs.

Indefinite subjects like 'somebody' (26a) and epithets (26b) (which are generally not accented, see Ladd 1996: 174-204 and Truckenbrodt 2007), support our generalization: they do not block SFF.

a. What's new?

KARla $_{\mathrm{i}}$ někdo hledal $\mathrm{t}_{\mathrm{i}}$.

Karel.acc somebody.nom looked-for.sg.ms

'Somebody was looking for Karel.'

b. What did Fritz do on Sunday?

$[\text { Ein } \mathrm{BUCH}]_{\mathrm{i}}$ hat der Idiot $\mathrm{t}_{\mathrm{i}}$ gelesen, anstatt

a book has the idiot read instead

schwimmen zu gehen.

swimming to go

'The fool read a book, instead of going swimming!'

Deaccentuation of an overt subject within wide focus is felicitous if a rich enough context enables its accommodation. (27c) is a possible case of SFF across an overt

\footnotetext{
${ }^{18}$ Rhythmical accents possible on verbs do not count here, see also Sect. 4.

${ }^{19}$ The interaction of DP-objects is more complex because of the existence of multiple 'base orders'. See Fanselow (2010) for discussion.

${ }^{20}$ Höhle (1979: 428-429) notes that the full lexical subject cannot be part of the focus in such constellations in German, Jacobs (1991: 9) remarks that pronominals and other phonologically weak elements are felicitous.
} 
subject in the context (27a): a party with very loud music evokes an expectation of annoyed neighbours. ${ }^{21}$ On the other hand, the same sentence as an out-of-the-blue utterance, e.g., in the context (27b), is not felicitous.
a. A: ... the music at the party was really loud. B: So what happened?
b. What's the matter? Why are you calling me so late at night?
c. [Den STROM $]_{i}$ hat uns der Nachbar $t_{i}$ ausgeschaltet ... the.acc electricity has us the neighbour switched-off 'Our neighbour has switched off the electricity.'

The following examples illustrate wide focus with a fronted accented subject.
a. Why did you do that?
MATka $_{\mathrm{i}} \mathrm{mi}$ to $\mathrm{t}_{\mathrm{i}}$ poručila.
mother.nom me.dat it ordered.sg.fm
'Mother ordered it to me.'
b. What happened?
[Eine KRANKENschwester $]_{\mathrm{i}}$ hat $\mathrm{t}_{\mathrm{i}}$ einen PaTIENten getötet.

a nurse has a.acc patient killed
'A nurse killed a patient.'

(Ge)

In (28a), the subject is the only available accented category. SFF movement of the subject is acceptable in the presence of further accented material as in (28b), too, because the subject is the leftmost accented element. Its SFF movement crosses no accented phrase. In the case of accented subjects as in (28b), the outcome of SFF movement is identical with the outcome of formal fronting, for obvious reasons.

Similarly, when both the subject and the direct object are weak pronominals or unaccented indefinites, the accented verb can undergo SFF, as it crosses no accented material on its way up to SpecCP, cf., e.g., (29).

$$
\begin{aligned}
& \text { What happened last Sunday? } \\
& \text { VerLETZT } \mathrm{T}_{\mathrm{i}} \text { hab' ich mich } \mathrm{t}_{\mathrm{i}} \text {. } \\
& \text { hurt have I myself } \\
& \text { 'I hurt myself.' }
\end{aligned}
$$

Multiple focus constellations show such restrictions on movement, too. Inversion of accented elements is impossible in answers to multiple wh-questions like (30) and (31). (30) illustrates a context with a single wh-operator unselectively binding two variables, as shown in the semantic representation in (30c). ${ }^{22}$ Importantly, both accented elements corresponding to the $w h$-phrases in the context question are contextually not given. The multiple wh-question in (31) has two operators, one taking scope over the other (cf. 31c). Again, they operate on sets of alternatives that are not contextually given.

\footnotetext{
${ }^{21}$ Speakers vary in their judgments of structures comparable to (27). We attribute this variation to differences in the ability and willingness to 'confabulate' contextual properties that license the deaccentuation of the subject.

${ }^{22}$ See van Hoof (2003: 528-533) for discussion of conjoined vs. matching focus.
} 
(30) So you came in and smelled food. Who cooked what?

a. KARL hat GUlasch gekocht.

Karl has goulash cooked

'Karl cooked goulash.'

b. \#Gulasch ${ }_{\mathrm{i}}$ hat KARL t $\mathrm{i}_{\mathrm{i}}$ gekocht.

c. $\mathrm{wh}_{\mathrm{x}, \mathrm{y}}, \mathrm{x}$ a person, $\mathrm{y}$ a dish, [x cooked $\left.\mathrm{y}\right]$

(31) There was a new cooking competition on TV. Who cooked what?

a. KLINk hat eine FoRElle gekocht und WIEner ein KaNINchen.

$(\mathrm{Ge})$

Klink has a trout cooked and Wiener a rabbit

'Klink cooked a trout and Wiener a rabbit.'

b. \#[Eine ForElle $]_{\mathrm{i}}$ hat KLINK $\mathrm{t}_{\mathrm{i}}$ gekocht und [ein KaNINchen $]_{\mathrm{k}}$ WIEner $\mathrm{t}_{\mathrm{k}}$.

c. $\quad \mathrm{wh}_{\mathrm{x}}, \mathrm{x}$ a person, $\mathrm{wh}_{\mathrm{y}}, \mathrm{y}$ a dish, [x cooked $\left.\mathrm{y}\right]$

In some cases involving two operators, however, crossing movement is possible, as already illustrated by (14), (16), and (18) above. Crossing movement seems licensed in two circumstances, viz. when one set of the focus alternatives is contextually given, as in (18), and when the accent crossed over falls on a functional element such as a focus particle that generally remains unaccented, as in (16). The cases of crossing movement thus have in common that one of the accents is not a structural one: it is borne by an element that is normally not accented because it is given or a functional category. We thus need to confine our generalization to elements bearing a structural accent in the sense of Selkirk (1995), which may not cross each other in moving to SpecCP.

\subsection{SFF is a syntactic movement}

Although the crucial locality restriction on SFF is based on accentuation, we will show that the fronting cannot be analysed as a post-syntactic PF-operation. In models in which PF movement and syntactic movement differ only in terms of whether LF has access to their outcome (Holmberg 2000), we would not gain much from analysing SFF movement as a PF process. The special role accentuation plays for SFF movement would not be explained any better than by syntactic movement. In other models, PF movement differs substantially from syntactic movement. For instance, head movement was taken to be PF movement by Chomsky (1995) because it does not respect the extension requirement. However, with the exception of the accent-sensitive intervention effect, SFF behaves like a normal A-bar-movement operation. For instance, in contrast to Stylistic Fronting (Holmberg 2000), SFF is not clause-bound but enters long distance dependencies.

a. What has she been doing there so long?

[Das AUto] $]_{i}$ denk ich hat sie versucht $\mathrm{zu}_{\mathrm{i}}$ reparieren!

the car think I has she tried to repair

'I think she has tried to repair the car!'

b. And what happened then?

[Ein TAxi $]_{i}$ hat sie gesagt dass sie sich $t_{i}$ nehmen wird.

a taxi has she said that she refl. take will

'She said she would take a taxi.' 
SFF is also island sensitive. In Czech, topic and (narrow-)focus fronting (in contrast to wh-movement) is compatible with weak islands (Meyer 2004: 188-195). SFF movement is not blocked by weak islands either, as illustrated in (33) with a $w h$-island. On the other hand, SFF movement obeys strong islands like adjunct clauses (34) (see also Lenertová and Junghanns 2007).

Why are you so angry?

Ále, [jeden blbej FORmulár̆] nevím, jak mám vyplnit $\mathrm{t}_{\mathrm{i}}$. $(\mathrm{Cz})$ prt one stupid form not-know.1sg how shall.1sg fill-in.inf

'I don't know how to fill in one stupid form.'

Are you not worried that Peter still does not know what he really wants?

a. * $\mathrm{SKOlu}_{\mathrm{i}}$ se rozhodne, až dokončí $\mathrm{t}_{\mathrm{i}}$ ! school.acc refl. decide. $3 \mathrm{sg}$ when finish. $3 \mathrm{sg}$

'He will decide himself when he has finished the school!'

b. Rozhodne se, až dokončí ŠKOlu! decide. $3 \mathrm{sg}$ refl. when finish.3sg school.acc

Finally, parasitic gaps lend further support to a syntactic analysis of SFF movement. Parasitic gap constructions do not exist in Czech, but German infinitivals as in (35) are often analysed as involving parasitic gaps (e.g., Bayer and Kornfilt 1994). ${ }^{23}$

Sie hatte dies $s_{i}$ ohne $e_{i}$ gelesen zu haben $t_{i}$ zurückgewiesen.

$(\mathrm{Ge})$ she had this without read to have rejected 'She had rejected this without reading it.'

(36) shows that parasitic gaps can be licensed by SFF movement. There is no reason to doubt, then, that $\mathrm{SFF}$ movement is a proper syntactic process.

\section{What did he do?}

AKten $_{i}$ hat er [anstatt $e_{i}$ zu bearbeiten] $t_{i}$ in den Papierkorb geworfen. (Ge) files has he instead to process in the basket tossed 'He threw files into the basket without having processed them.'

We are thus confronted with a syntactic movement that cannot be analysed as an attraction of a syntactic focus (or other pragmatic) feature (see Sect. 5 for a discussion and rejection of possible feature-checking accounts of SFF) and shows locality restrictions sensitive to accentuation. In the following section, we will propose an analysis of left-periphery-movement that explains the properties of SFF.

\footnotetext{
${ }^{23}$ Fanselow (2001) and Kathol (2001) propose to not analyse (35) as a parasitic gap construction. Zwart (1997) also argues that Dutch counterparts of (35) do not behave like genuine parasitic gaps.
} 


\section{A linearization-based analysis of SFF}

\subsection{Architecture of the grammar and SFF}

Most syntactic ingredients of our analysis of SFF movement have been introduced in the preceding discussion. The choice of the element that goes to the first position of a Czech and German clause is practically free in declaratives: subjects, various types of adverbs, topics, foci, parts of foci, and other categories can move to SpecCP. We conclude that LP-movement is altruistic, in the sense that the displacement does not satisfy any requirement of the moved phrase. Specifically, we assume that LPmovement is triggered by an unselective edge feature of $\mathrm{C}$ (Chomsky 2008) requiring a filled SpecCP in all root and some embedded clauses. ${ }^{24}$

Our Czech and German examples show that XPs can in principle cross ccommanding phrases when they undergo LP-movement to SpecCP, as expected if syntax contains no Minimal Link Condition that would prevent such crossing movement (Chomsky 2008). When we consider SFF, it remains to be explained why movement is nevertheless blocked by intervening (structurally) accented categories. ${ }^{25}$

Prosodic prominence is the primary way of focus realization in languages like Czech and German. We assume an interpretive approach to focusing, in which accentuation applies freely in the course of the syntactic derivation. The freely assigned prosodic shape of a sentence determines which pragmatic contexts the sentence is compatible with. The status of a syntactic object $\mathrm{K}$ as being (potentially) in focus can be computed on the basis of the presence and location of accents in $\mathrm{K}$, taking into account interface constraints (see, e.g., Büring 2007 and Schwarzschild 1999).

In a minimalist approach, the syntactic, prosodic, and semantic derivations operate in a quasi-parallel fashion, being synchronized with the completion of phases. Lexical items, and, therefore, also syntactic objects are triplets specifying phonological, syntactic, and semantic information. ${ }^{26}$ The information as to whether a certain category $\mathrm{K}$ dominates a node that is accented can thus be read off the syntactic tree when phases are interpreted. A representation of focus in terms of F-marking (Jackendoff 1972) designed as a tool for mediating between prosody and interpretation is thus superfluous. It found its motivation only within the limits of the GB model (Chomsky 1981), in which there was no direct communication between PF and LF so that the information whether some category is accented or not had to be transported through

\footnotetext{
${ }^{24}$ Sentences in which the finite verb comes first can be found in Czech, German and most other V2 languages. We will have to leave it open here whether such sentences involve an empty operator in SpecCP (as argued, e.g., by Roberts 1993 for Yes/No Questions) or are constructed with a C node lacking an edge feature.

${ }^{25}$ The leftmost accented XP is normally also the structurally highest XP with an accent. The model we develop in this section in fact implies that accented XPs must c-command and precede YP for exerting intervention effects on leftward movement. Given the strong correlation between hierarchy and linear order, it is very hard (if not impossible) to find constructions in which a phrase following $\mathrm{ZP}$ c-commands $\mathrm{ZP}$ that would allow us check whether intervention conditions are adequately characterized by the conjunction of precedence and c-command.

${ }^{26}$ The theory of Distributed Morphology follows a different architecture, see, e.g., Halle and Marantz (1993).
} 
syntax to the interpretive component of grammar (see Szendrói 2001 and Horvath 2007 for discussion).

The most notable property of SFF movement - that it can affect the leftmost accented phrase only-cannot be accounted for by a direct reference to accentuation restricting the syntactic movement. The intervention restrictions will be analyzed as a side-effect of linearization, the syntactic property underlying default/structural accentuation. In other words, the locality constraint on SFF will be attributed to restrictions on ordering statements in linearization. It is crucial for the proposed account to differentiate between default structural accent (phrase stress) and pragmatically determined accent in sentences containing contrastive focus and given elements (see, e.g., Jackendoff 1972 and Zubizarreta 1998). Only the former is bound with linearization and thus relevant for movement restrictions in SFF contexts.

\subsection{Intervention effects in SFF and cyclic linearization}

Our account of the intervention effect of accented categories on SFF is based on insights of Fox and Pesetsky (2005), who propose that the linearization of syntactic structures is coded in the form of ordering statements $\mathrm{X}>\mathrm{Y}$ established in a phaserelated fashion. Crucially, once an ordering statement has been created, it cannot be altered or abandoned later. If the derivation cannot proceed but by entering an ordering statement incompatible with previous ones, the derivation crashes. We propose that the model can be modified such that it captures LP-movement and therefore SFF movement in Czech and German. If one makes sure that accented XPs are linearized before they move, they cannot cross each other.

Fox and Pesetsky (2005) share the standard minimalist assumption that spellout is a cyclic process. They introduce spellout domains such as $\mathrm{CP}$, roughly corresponding to phases in the standard minimalist sense. When a spellout domain has been constructed, a complete linearization of the phrases included in that domain is computed.

This leading concept of cyclic spellout is compatible with the more liberal view that ordering statements may (in principle) be entered at any point in the derivation, and not just when a spellout domain has been completed. In such a model, UG leaves it open when two phrases are linearized, but linearization must have been fully computed when the derivation proceeds to the next spellout domain/phase. This is the version of cyclic spellout that we will (crucially) assume in this paper.

Once $\alpha$ and $\beta$ have been linearized, their relative order can no longer be changed. In order to prevent an accented category $\alpha$ from crossing a further accented category $\beta$, it must only be made sure that accented phrases are linearized before they move. Then they cannot cross each other. The constraint that we call Early Accentuation (EA), given in (37), has this effect.

\section{Early Accentuation (EA)}

Structural accents are determined when phrases are merged.

As mentioned above, phrases can in principle be linearized at any point in the derivation before the spellout domain/the phase they sit in is sent off to the interfaces. EA constrains the flexibility of this system, because structural accentuation presupposes linearization. After all, the relative prosodic prominence of a category depends 
on whether it sits on a left or a right branch, in a language- and category-specific fashion. For instance, adjectives are prosodically more prominent than nouns in Hungarian (38a) but not in English (38b), because left branches are stronger than their sisters in Hungarian, but not in English (e.g., Szendrői 2001). The prosodic strength of a branch can only be determined when it has been linearized.
a. a piros autó
b. the red car

EA requires that structural accentuation happens when phrases are merged; because of the link between order and prosodic strength. EA therefore implies that phrases bearing structural accents must be linearized as soon as they are merged.

The intervention effect of accented phrases for SFF then follows from EA in a very direct way. Suppose that Comp possesses an edge feature in (39), and that $\alpha$ and $\beta$ are structurally accented.

$$
[\operatorname{Comp} \ldots[\mathrm{w} \ldots[\alpha \ldots[\mathrm{z} \ldots[\ldots \beta \ldots] \ldots] \ldots] \ldots] \ldots]
$$

Because of their accentuation, EA implies that $\alpha$ and $\beta$ have been linearized immediately when they were merged. This means that an ordering statement $\alpha>\mathrm{Z}$ has been created. $\mathrm{Z}$ dominates $\beta$, and because $\beta$ has already been linearized in $\mathrm{Z}$ (because it is structurally accented), the ordering $\alpha>\beta$ is implied, which must not be changed later. Consequently, $\alpha$ can move to SpecCP (because this leaves the ordering statement $\alpha>\beta$ intact), but $\beta$ cannot move across $\alpha$.

Suppose, on the other hand, that $\alpha$ in (39) does not bear a structural accent. EA then leaves it open whether $\alpha$ is linearized immediately or not. If it is, it will exert a blocking effect on the movement of $\beta$. In the case of unaccented $\alpha$, this may cause the crashing of the derivation (if $\beta$ must move but is prevented from doing so because of the ordering $\alpha>\beta$ ). This is unproblematic, however, because there is an alternative derivation in which unaccented $\alpha$ is not linearized immediately, so that $\beta$ can cross it. The movement of accented $\beta$ across unaccented $\alpha$ is therefore not ruled out, as required. The basic distinction we observe in SFF movement is thus derived: an element can be fronted only if it is the leftmost accented category. The failure of immediate linearization (and consequently the absence of stress assignment) may be considered the structural correlate of givenness (but see below). ${ }^{27}$

Let us flesh out the system we propose in a bit more detail. We assume that linearization is immediate if it applies directly after (or as a side-effect of) an (external) merge operation. This seems to conflict with the idea that phrases are spelt out in the context of feature valuation (or after valuation), see Epstein and Seely (2002) for discussion. Consider subjects of unaccusative verbs in this respect. They are merged

\footnotetext{
${ }^{27}$ As noted in Sect. 3.2, we follow the common assumption that non-given arguments are obligatorily accented. Consequently, (37) requires that all non-given XPs will be accented when they are merged. In that respect, the goal of (37) differs from a number of proposals which try to explain accentuation in a phase-based model (Adger 2007; Ishihara 2007; Kahnemuyipour 2004, and Kratzer and Selkirk 2007). These approaches attempt to identify the location of the 'sentence (nuclear) accent', the most prominent structural accent of a clause. Since sentence accents play no particular role in SFF movement (it is the leftmost structural accent that moves, not the prosodically most prominent one), we need not discuss here which of these models is best compatible with our approach.
} 
as complements of $\mathrm{V}$, but their Case depends on agreement with $\mathrm{T}$, so they cannot be spelt out completely before $\mathrm{T}$ is merged.

However, the subject rather than the verb is stressed in unaccusative constructions with wide focus reading, see (41). The explanation of this difference implies that unaccusative subjects are accented in the position of $\beta$ rather than $\alpha$ in (40) (e.g., Adger 2007).

$$
\begin{aligned}
& \text { [тр } \alpha \mathrm{T}[\ldots[\mathrm{V} \beta]] \\
& \text { What's the matter? }
\end{aligned}
$$

a. The BABY's disappeared.

b. *The baby's DISAPPEARED.

The demands of immediate linearization and spellout in the context of/after complete valuation are compatible, however. After all, the determination of linear order and accents is just one aspect of spellout, which can precede the computation of the final phonological realization. In particular, the presence of linearization statements does not exclude further featural valuation in an obvious sense.

In Fox and Pesetsky (2005), the size of the spellout domains determines which nodes must be targeted as cyclic movement steps. An accented and thus instantaneously linearized phrase $\beta$ can cross $\alpha$ in (39) as long as $\beta$ moves before $\alpha$ has been linearized relative to $\beta$. The structural accentuation of $\alpha$ linearizes $\alpha$ relative to $\beta$, as required. However, $\alpha$ must always be linearized before the derivation proceeds beyond $\mathrm{W}$, if $\mathrm{W}$ is a spellout domain. In that case, $\beta$ must move to the edge of $\mathrm{W}$ before $\alpha$ is linearized, i.e., it must undergo cyclic movement. Note that this cyclic movement step helps to overcome intervention effects of $\alpha$ only if $\alpha$ is not structurally accented.

So far, we have confined our attention to arguments (and adjuncts). Verbs play a special role because they are usually unaccented even when they are [-given], as remarked above. There, we also saw that verbs do not block SFF-movement of an argument. In an SOV language like German, such a blocking effect is not to be expected in any event, because the verb follows its arguments and is thus unable to trigger intervention effects. Things are different in the SVO language Czech: the verb precedes its object (42b), so that the mobility of XP indeed depends on the status of $\mathrm{V}^{28}$

$$
\begin{array}{ll}
\text { a. } & {[\mathrm{XP} \mathrm{V}]} \\
\text { b. } & {[\mathrm{V}[\mathrm{XP}]]}
\end{array}
$$

For our purposes, it suffices to assume that verbs cannot participate in immediate linearization. Due to the failure of immediate linearization, verbs move easily across accented arguments ${ }^{29}$ and adjuncts, e.g., in a verb second construction, which requires that the German vP (43a) be eventually mapped onto (43b). If den Hund and

\footnotetext{
${ }^{28}$ The failure of the verb to trigger intervention effects for SFF movement in Czech shows that SFF movement cannot be recast in terms of a feature [-given] (see, e.g., Féry and Samek-Lodovici 2006 for the proposal of G(ivenness)-marking). The verb is [-given] in wide focus contexts, but it can be crossed by accented objects.

${ }^{29}$ Once $\mathrm{V}$ is ordered in Comp or Tense, no element in TP and vP can be moved across V to SpecCP and SpecTP, respectively. UG allows the serialization of the finite verb after the specifiers of TP and CP have
} 
sah were ordered with respect to each other when they were merged, the verb could never move across the direct object. ${ }^{30}$
a. $\quad\left[{ }_{v P}\right.$ er [vp[den HUND] sah]]
he the dog saw
b. $\quad \operatorname{Er}[$ sah [vP den HUND tv]]
'He saw the dog.'

All XPs can be accented in a (wide focus) construction, but they do not have to be so. The absence of an accent on a phrase is visible to, and can be made sense of, by the interpretive component, which can take unaccented XPs to be given. Furthermore, the interpretive 'focus projection' can also apply in the usual fashion-with a phrase being a potential focus if it contains an accented word in certain structural constellations allowing it to be maximally prominent (see Büring 2006 for discussion of focus projection). Our model thus adheres to current explanations of the relation between accentuation and focus (projection).

\subsection{Secondary linearization}

Phrases with a structural accent cannot cross each other in our model. This captures SFF constructions in a direct way. For the interaction of accented phrases, our proposal has much in common with the analysis proposed in Fox and Pesetsky (2005): there is no crossing movement when the phrases have been serialized relative to each other before movement. However, in our model, accented phrases are serialized immediately, so they cannot even escape each other's intervention effects by moving to the edge of a spellout domain.

How is (structurally) unaccented material treated in our model? Such syntactic objects need not be serialized immediately. The exemption from obligatory immediate linearization gives them some freedom of movement, and prevents them from acting as interveners for the movement of material already linearized. This greater flexibility also distinguishes our model from the proposal of Fox and Pesetsky.

Unaccented material must eventually be serialized, and the fact that spellout is bound to certain domains excludes the idea that unaccented XPs are linearized at the end of the complete derivation. We will call linearization of material that has not undergone immediate serialization 'secondary linearization'. Let us discuss three relevant subcases: (a) wh-movement and scrambling, (b) formal fronting, and (c) movement of contrastive elements.

been filled (or after the insertion of an expletive), and for most cases, this is the only derivation that does not crash. See below for the role spellout domains play for verb movement.

${ }^{30}$ In the constellation [V V DP], it is unclear what the object is ordered with when it is immediately linearized if $\mathrm{V}$ does not undergo linearization itself. There are several solutions for this problem. We propose that the linearization of $\alpha$ in a tree $\mathrm{T}$ means that $\alpha$ is entered into the set $\mathrm{S}$ of elements ordered in T. If $\mathrm{S}$ has a single member only, ordering statements are trivial. Once further elements are entered into $\mathrm{S}$, they must be ordered relative to the other members of $\mathrm{S}$. 


\subsubsection{Wh-movement and scrambling}

Wh-words like who or what (and their German and Czech counterparts) are typically unaccented when they go to SpecCP (Bresnan 1972; Kahnemuyipour 2004). Immediate linearization is optional, which means that wh-phrases do not have to be linearized directly after being merged. Above, we have said that the failure to undergo immediate serialization is the structural correlate of givenness, which seems true for most deaccented phrases but certainly not for $w h$-expressions. We assume that $w h$ phrases in SpecCP are exempted from being interpreted as given because they are in a local agree relation with a $[+$ wh]-feature overriding the accentuation-based interpretation. $^{31}$

The wh-phrase moving to SpecCP is unaccented and thus not serialized immediately. At the same time, its movement is not blocked by intervening accented XPs, cf. (44). Such a flexibility of movement is, however, not guaranteed in the system presented so far.

$$
\begin{aligned}
& \text { Wen mag jeder Kritiker } \mathrm{t}_{\mathrm{wh}} \text { ? } \\
& \text { who.acc likes every critic } \\
& \text { 'Who does every critic like?' }
\end{aligned}
$$

The difficulty stems from the assumption of Fox and Pesetsky (2005) that spellout domains are linearized completely once they have been completed. Suppose that $\mathrm{Z}$ in (39) — repeated here as (45) for convenience-is a spellout domain, and that $\alpha$ is structurally accented. Then $\beta$ cannot move across $\alpha$ even if $\beta$ is unaccented and moved to the edge of $\mathrm{Z}$, because the relative linear position of $\beta$ in $\mathrm{Z}$ will have to be fixed when $\mathrm{Z}$ is completed, and because the ordering statement $\alpha>\mathrm{Z}$ (hence $\alpha>\beta$ ) is established when accented $\alpha$ is merged.

$$
[\text { Comp ... }[\mathrm{w} \ldots[\alpha \ldots[\mathrm{z} \ldots[\ldots \beta \ldots] \ldots] \ldots] \ldots] \ldots]
$$

We will take up the proposal of Müller (2007) and assume that phases rather than spellout domains are relevant for linearization. According to Müller, the completion of a phase (CP, vP) implies that the complement of the phase's head must be spelt out. ${ }^{32}$ The intermediate movement steps of a $w h$-phrase moving cyclically place the $w h$-phrase into the edge of a phase, so that it does not have to be linearized when the phase is completed. Not being linearized, unaccented $w h$-phrases are not subject to intervention effects triggered by c-commanding XPs with a structural accent, as required. Eventually, the unaccented $w h$-phrase is serialized when it checks the edge feature of Comp.

(A-)Scrambling is (usually) restricted to given phrases (see Haider and Rosengren 2003 for German and Kučerová 2007 for Czech). The category that moves is unaccented, and has thus not been linearized immediately. Therefore, intervention effects

\footnotetext{
${ }^{31}$ See Zubizarreta (1998) for a related proposal.

${ }^{32}$ Holmberg's generalization on Scandinavian Object Shift (the object moves only if the verb moves, too), which figures as one of the major arguments for cyclic linearization in Fox and Pesetsky (2005), can be derived under the following two assumptions: (a) object shift moves the object out of vP, without intermediate movement steps, and (b) $\mathrm{V}$ does not reach the head position of $\mathrm{vP}$ when it does not move out of vP. A detailed discussion is beyond the scope of the paper.
} 
triggered by structurally accented XPs are not to be expected. This prediction is borne out, as (46) shows. ${ }^{33}$

\section{Who tore the book up?}

Ich meine, dass [das Buch $]_{i}$ der $\quad$ INGO t $t_{i}$ zerrissen hat.

I think that the book the.nom Ingo torn has

'I think Ingo tore up the book.'

\subsection{2 'Formal fronting'}

In Sect. 2.2, we discussed movement to SpecCP in the absence of any particular pragmatic specification (FF-movement). (47) illustrates deaccented pronouns in German, for scrambled objects see (50) below.

\footnotetext{
Why does Anna cry?

Sie hat viel Geld verloren.

she has much money lost

'She has lost a lot of money.'
}

Fanselow (2002) assumes a structural grid such as (48), and invokes the MLC of Chomsky (1995) to guarantee that only the leftmost element of the left periphery is attracted in an FF construction.

\section{[C [те (sent. adverb) [(temp. adverb) [(scrambled) [TP subject [ ${ }_{\mathrm{vP}}$} (scrambled) ... []]]]]]

In contrast, the present approach predicts no privileged access of the leftmost element in TP to SpecCP: if $\alpha$ has not received a structural accent, it is not linearized immediately, so it will neither be subject to intervention effects nor trigger them. Only phase theory restricts movement in such a case. Any unaccented $\alpha$ not included in the complement of the vP-phase can move to SpecCP.

Deciding between left-periphery theories of FF (Fanselow 2002; Müller 2004) and the present approach turns out to be a non-trivial task. Note that the observations brought forward by Fanselow and Müller only show that elements in SpecCP must also be able to figure as the leftmost element in TP. This does not imply that FFmovement to SpecCP originates in the left periphery of TP. Even if FF-movement could start only there, the empirical effect of this restriction would be small: unaccented XPs generated in vP can be scrambled and adjoined to any segment of TP, so they can easily reach the leftmost point of TP in an intermediate scrambling step.

However, certain adverbs may decide the issue. Ernst (2002) and Engels (2004) point out that the subject-oriented interpretation of adverbs such as klugerweise 'cleverly' arises only when the adverb is c-commanded by the subject (49a vs. 49b). Engels continues to observe that this restriction need not be respected by movement to SpecCP $(49 \mathrm{c}-\mathrm{d})$, and notes that this is incompatible with the MLC-based model of

\footnotetext{
${ }^{33}$ If scrambling is triggered by an edge feature, serialization can take place when the edge feature is checked. See Fanselow (2010) for further remarks on A-scrambling.
} 
$\mathrm{FF}$, in which (49b) is the only source of (49d). In our present approach, unaccented Anna triggers no intervention effects, so that (49d) can also be derived from (49a). The reading difference between (49b) and (49d) thus supports the present approach.

(49) a. dass Anna klugerweise Maria einlud. (subject oriented reading — ok) that Anna cleverly Mary invited 'that Anna cleverly invited Mary.'

b. dass klugerweise Anna Maria einlud. (subject oriented reading - *)

c. Anna lud t klugerweise Maria ein. (subject oriented reading - ok)

d. Klugerweise lud Anna t Maria ein. (subject oriented reading — ok)

Consider also the data in (50). Given objects can cross a given subject in adverb focus contexts. Because given objects can undergo scrambling, the derivation of (50b) might involve an intermediate movement step in which the object scrambles to the left of the subject, and is then mapped to SpecCP by FF-movement respecting the MLC. However, (50a) cannot possibly be derived in this way. Subject pronouns cannot be preceded by scrambled material in TP (50c). Movement of den Jan to SpecCP therefore has to cross the subject sie. This is incompatible with MLC-based approaches (in particular, sie might have moved to SpecCP, too) but it can be easily captured in our proposal: neither sie nor den Jan are structurally accented, so their movement to SpecCP is unrestricted.

Tell me something about Anna. When did she call Jan?

a. [Den Jan $]_{i}$ hat sie am FREItag $t_{i}$ angerufen. the.acc Jan has she on-the Friday called 'She called Jan on Friday.'

b. [Den Jan $]_{i}$ hat $\left(t_{i}\right)$ die Anna am Freitag $t_{i}$ angerufen. the.acc Jan has the Anna on-the Friday called 'Anna called Jan on Friday.'

c. Wahrscheinlich hat *(den Jan) sie (den Jan) am FREItag probably has she the.acc Jan on Friday angerufen. called 'Probably, she has called Jan on Friday.'

FF and SFF constructions thus arise because of an unspecific edge feature of Comp. Wh-movement is also effected by the very same edge feature of $\mathrm{C}$, but the whcriterion forces that only a $w h$-phrase can move when $\mathrm{C}$ possesses a + wh feature (and excludes the attraction of $w h$-phrases in case of a [-wh] C, but see Müller and Sternefeld 1996).

\subsubsection{Multiple foci/contrastive topics}

In Sects. 4.3.1 and 4.3.2 we have discussed cases in which unaccented material crosses accented material. Crossing is not confined to deaccented phrases, however. 
XPs with structural accents cannot cross each other. ${ }^{34}$ Structural accentuation is, however, not the only way by which a phrase may receive accent — an element can also be accented if it is contextually given, e.g., if it is a contrastive topic/focus. In line with Jackendoff (1972), Rochemont (1986), and Zubizarreta (1998), we assume that these contrastive accents are not to be treated on a par with structural accents. They can be assigned at any point in the derivation to XPs not accented previously and are interpreted along the lines for structural accents: the pertinent discourse functions are computed on the basis of the location of the accents in the tree in accordance with interface constraints (see, e.g., Büring 2007). In case a phrase ends up being unaccented, it is interpreted as merely given, and if it receives a non-structural accent, this accent corresponds to the appropriate information-structural interpretation.

We have already seen that given/unaccented material undergoing late linearization can cross structurally accented material, so the extension of our model to nonstructural accents leads to the expectation that this crossing option also exists for given material with contrastive accents. After all, the factor triggering intervention is not the presence of an accent but the relative timing of the creation of ordering statements. This prediction is borne out: contrastive foci/topics in pair-list/distributive contexts may cross structurally accented foci (cf. example (18) in Sect. 3). The moved elements are contextually given and receive the rising accent at a later point in the derivation.

On the other hand, elements with a structural accent may cross an element that is accented but given. In (51), the subjects are given due to the pair-list/distributive context question, they are not linearized immediately and receive their contrastive accents later. ${ }^{35}$

a. A: What did the children/Peter and Mary cook?

B: [Eine Suppe] ${ }_{i}$ hat PEter $t_{i}$ gekocht und [einen Auflauf] $]_{j}$ MaRIa $t_{j}$. (Ge) a soup has Peter cooked and a.acc pie Mary 'Peter cooked a soup and Mary a pie.'

b. A: What did the children/Peter and Mary do?

B: [Eine Suppe $]_{i}$ hat PEter $t_{i}$ gekocht und EINgekauft hat MaRIa. a soup has Peter cooked and shopped has Mary 'Peter cooked a soup and Mary did the shopping.'

The answer in (52) is possible only if a contextually given set of Fritz and Irina (and $\mathrm{Karl}$ ) may be accommodated, i.e., the subject Irina may be interpreted as given. Otherwise, Irina is newly introduced (see also Neeleman and van de Koot 2008), and as such it obligatorily receives a structural accent, which leads to an intervention effect with the fronted focused object.

\footnotetext{
${ }^{34}$ Recall that multiple $w h$-contexts where both elements are not contextually given do not allow inversion. The elements receive structural accents and undergo immediate linearization (cf. examples (30)-(31) in Sect. 3.2).

${ }^{35}$ Examples (14) and (16) in Sect. 3 represent a slightly different case, the crossed elements being functional elements that do not receive structural accents.
} 
A: What has Fritz read?/What has Fritz done?

B: Weiß ich nicht. Aber [eine KuRZgeschichte] $]_{i}$ hat IRIna $t_{i}$ gelesen...(Ge) know I not but a short story has Irina read 'I don't know, but Irina read a short story (and Karl a fairytale/and Karl finished his paper).'

We conclude that the necessary condition for the possibility of accent crossing is that the two participating elements are not both structurally accented. In rise-fall constructions, crossing is limited to contexts rendering one of the participants contextually given (or to contexts with one of the participants being a functional expression), which results in constellations where only one of the participants receives a structural accent. It is not important whether the fronted categories are contrastive topics or foci or their parts, as long as this condition is fulfilled. Accentuation of given elements is further subject to interface conditions: contrastive topics and foci ultimately have to receive an accent, accent marking of topics is optional. ${ }^{36}$

\section{SFF vs. feature-checking movement}

\subsection{Attraction of accents}

Phrases act as interveners in SFF constructions depending on their accentuation. One might be tempted to account for this in a more direct way than in the model we are proposing, viz. by assuming that 'accentuation' figures as a syntactic feature and licenses movement, as we have ourselves proposed in earlier work. However, there are reasons that militate against the idea that SFF can be licensed by agreement for an 'accentuation' feature.

First, being accented is not a lexical feature, so the use of accentuation as a trigger of syntactic movement violates the inclusiveness condition. ${ }^{37}$ A theory of movement that refers directly to phonological properties also has to explain why accentuation is the only aspect of phonology that triggers/licenses movement. The obvious answer is that accentuation is determined by syntactic properties. But then, it is more plausible to explain movement in terms of the syntactic factors controlling accentuation rather than in terms of accentuation itself.

A second argument against accent-driven movement as an account of SFF lies in the fact that subparts of foci can also be fronted in languages that do not have (obligatory) focus marking by stress (for focus in situ). Object fronting is compatible with a wide focus interpretation in Hausa, as observed by Hartmann and Zimmermann (2007). Idioms can be split in Hausa, too, with only the direct object being fronted

\footnotetext{
${ }^{36}$ Second occurrence foci $(\mathrm{SOFi})$ represent a special case, as their prosodic marking differs from other cases of foci, see, e.g., Féry and Ishihara (2009). Crucially, SOFi undergo secondary linearization: they are contextually given and thus not structurally accented.

${ }^{37}$ Prosodically driven movement as proposed by Zubizarreta (1998) and Szendrői (2001) is different: it does not displace a phrase on the basis of an already present prosodic property. Zubizarreta's account concerns removing elements from the domain of stress assignment, Szendrói considers cases in which a constituent moves because it can be stressed in the landing position only.
} 
(Newman 2000: 261). Gurune (Andreas Haida, p.c.) and Somali (Svollacchia et al. 1995) behave in the same way. SFF constructions also exist in Trinidadian English, where focused elements need not be accented, and in Haitian Creole as in (53), where stress cannot be used for focusing, as Franz Cozier argues in an unpublished manuscript (MIT, 2006).

What are you doing there?
a. Se kuit map kuit poul.
(Haitian Creole, F. Cozier, Ms.) it is cook I pres.prog cook chicken
b. Se poul map kuit.
it is chicken I pres.prog cook
'I am cooking chicken.'

That SFF movement also occurs in languages without a prosodic marking of focus would be left unexplained in a theory that directly relates the construction to a prosodic property, even if the latter is understood in a rather abstract way.

\subsection{The focus-feature checking approach to SFF}

In this section, we argue that SFF (and FF) constructions cannot be captured in terms of feature checking of focus or topic phrases. First, no other type of operator movement allows it that just a subpart of the relevant element checks the operatorrelated feature. One might see certain parallels between SFF and subextracting $w h$ movement available in French (54a) or in Czech. However, the wh-operator itself is the word bearing the $w h$-feature, and not the DP dominating this word. Therefore, the English equivalent in (54b) involves pied-piping of a DP, while (54a) exemplifies $w h$-movement without pied-piping and not partial fronting. This is not parallel to SFF phenomenon, where a subpart of a focus-marked phrase undergoes fronting.

$$
\begin{aligned}
& \text { a. Combien as-tu lu de livres? } \\
& \text { b. How-many have-you read of books } \\
& \text { b. hooks have you read? }
\end{aligned}
$$

(French)

In order to cope with this problem in a model that analyses SFF constructions as focus-feature checking movement, one would have to assume that it is always the focus XP that is attracted, and that 'partial' fronting is the result of constituents of XP being removed from that category before it moves, i.e., that SFF involves remnant movement in the sense of Müller (1998), or some sort of scattered deletion. We will argue that neither of these possibilities can capture SFF appropriately. ${ }^{38}$

\subsubsection{Evidence against SFF as remnant movement}

Remnant movement constructions bear a certain resemblance to SFF constructions. In an SFF construction, the overt material in SpecCP is just part of the focus. Remnant movement theory as discussed in Müller (1998) proposes that the overt fronting

\footnotetext{
${ }^{38}$ Thanks are due to the anonymous reviewers for prodding us into a more detailed discussion of the relation between SFF and remnant movement or scattered deletion.
} 
of part of an XP must often be analysed as the movement of the complete XP, out of which the parts apparently remaining in situ have been scrambled before XP was moved. In this sense, SpecCP is filled by VP in (55), but the object was moved (scrambled) out of that VP before the remnant was fronted.

$$
\begin{aligned}
& {\left[\mathrm{t}_{\mathrm{i}} \text { gesehen }\right]_{\mathrm{VP}} \text { hat er nur eine EUle } \mathrm{t}_{\mathrm{VP}} \text {. }} \\
& \text { seen has he only an owl } \\
& \text { 'He only saw an owl.' }
\end{aligned}
$$

In an analysis of SFF as remnant movement of focus phrases, some material leaves the attracted focus VP/IP before the focus moves to the left periphery (see Cozier's 2006 account of focus movement in Trinidadian English). The constellation of a remnant movement analysis for SFF is given in (56-57) for VP- and IP-focus contexts, respectively.

\section{What did she do?}

a. [Den GARaus $\left.\mathrm{t}_{\mathrm{i}} \mathrm{t}_{\mathrm{j}}\right]_{\mathrm{VP} / \mathrm{FOC}}$ hat sie $\mathrm{ihm}_{\mathrm{i}}$ gemacht $\mathrm{t}_{\mathrm{VP}}$.

$$
\text { the garaus has she him.dat made }
$$

'She killed him.'

b. [Den GARaus $t_{i}$ gemacht $]_{V P / F O C}$ hat sie $i m_{i} t_{V P}$.

\section{What happened?}

a. $\quad\left[t_{i} \text { den GARaus } t_{j} t_{k}\right]_{I P / F O C}$ hat $\operatorname{sie}_{i} i_{h m_{j}}$ gemacht $_{k} t_{I P}$.

b. $\quad\left[t_{i} \text { den GARaus } t_{j} \text { gemacht }\right]_{I P / F O C}$ hat $\operatorname{sie}_{i} i{ } m_{j} t_{I P}$.

Note, first, that focus preposing indeed often involves remnant movement in German and Czech. A clear and undisputable case of remnant movement involves constructions in which, descriptively speaking, more than a single constituent surfaces to the left of the finite verb, but the material preceding the finite verb is actually a constituent, viz. a VP that lost its verbal head, see Fanselow (1993) and Müller (2003). Consider (58). The overt material in SpecCP consists of two parts of an idiomatic VP. A remnant VP-preposing analysis with the verb gegangen leaving VP before VP moves is inevitable if one wants to maintain that single constituents only can reach SpecCP. Pragmatically, (58) thus exemplifies fronting of a subpart of the focus due to remnant movement.

$$
\begin{aligned}
& \text { What did you do on Helgoland in the evenings? } \\
& \text { [VP [PP Mit den Hühnern] [PP ins Bett] } t_{V} \text { ] bin ich gegangen } t_{V P} \text {. } \\
& \text { with the chicken into bed am I gone } \\
& \text { 'I went to bed early.' }
\end{aligned}
$$

However, not all SFF constructions are amenable to such a treatment. For remnant movement of XP to SpecCP, the operation evacuating XP before movement is scrambling. German has no long-distance scrambling (Müller and Sternefeld 1993). This restriction explains the ungrammaticality of remnant VP-fronting examples such as (59), because the category left behind by remnant movement would have to be extracted by scrambling out of an embedded finite clause (59a) or a CP-infinitive (59b\&c). 
a. *[Gesagt, dass sie sich $\mathrm{t}_{\mathrm{i}}$ nehmen wird] hat sie ein TAxi $\mathrm{i}_{\mathrm{i}}$.

$(\mathrm{Ge})$ said that she refl. take will has she a taxi

'She said she would take a taxi.'

b. *[Gedrängt $t_{i}$ aufzugeben] hat sie ihn seinen $\mathrm{JOB}_{\mathrm{i}}$. urged give-up.inf has she him.acc his job

c. *[t $\mathrm{t}_{\mathrm{i}}$ Aufzugeben gedrängt $]$ hat sie ihn seinen $\mathrm{JOB}_{\mathrm{i}}$. 'She urged him to give up his job.'

Corresponding SFF examples are grammatical, however, as (60) shows. A remnant movement analysis for (60) would have to involve illicit long scrambling. (60) thus cannot be interpreted as remnant VP movement.

a. What did she do?

[Ein TAxi $]_{i}$ hat sie gesagt, dass sie sich $t_{i}$ nehmen wird.

a taxi has she said that she refl. take will

'She said she wants to take a taxi.'

b. How did she upset him?

$[\text { Seinen } \mathrm{JOB}]_{\mathrm{i}}$ hat sie ihn gedrängt $\mathrm{t}_{\mathrm{i}}$ aufzugeben.

his.acc job has she him.acc urged give-up.inf

'She urged him to give up his job.'

Finally, the parasitic gap data introduced above (cf. (36)) also militate against a remnant VP-movement analysis of SFF: the parasitic gap bound by the element undergoing SFF is a DP, not a VP.

Another problem for the remnant movement idea arises from a restriction on VPtopicalization. As observed by Haider (1990) and Diesing (1990), nominative subjects can be part of a fronted constituent if they are not definite, as seen in the difference between (61a) and (61b). This definiteness effect does not arise with all predicates, as shown by the contrast in (62). ${ }^{39}$ Importantly, corresponding SFF structures do not show any definiteness effects with subjects, cf. (63).

a. [Ein Orden verliehen] wurde ihr erst gestern.

a.nom medal awarded was her.dat only yesterday

b. *[Der Orden verliehen] wurde ihr erst gestern. the.nom medal awarded] was her.dat only yesterday

a. *[Der Papst angekommen] ist hier noch NIE. the pope arrived is here yet never

'The pope has never arrived here.'

\footnotetext{
${ }^{39}(61)-(62)$ are taken from Wurmbrand (2001). She attributes the restriction on topicalization in (61) to the ungrammaticality of TP-fronting in German. If definite subjects have to overtly move to TP (Diesing 1990), (61b) would have to involve TP-fronting, which is ungrammatical. In contrast, the indefinite subject in the grammatical (61a) stays in the vP, which can be fronted. As SFF cases like (63) would involve (remnant) TP-fronting under the remnant movement analysis, their grammaticality would have to receive a special account.
} 
b. [Der Papst begegnet] ist mir noch NIE. the pope encounter is me.dat yet never 'I have never met the pope.'

What happened?

a. Der PAPST ist mir begegnet!

the pope is me.dat encountered

b. Der PAPST ist angekommen!

the pope is arrived

Finally, a difference between SFF with VP-focus and VP-fronting can be observed in Czech. The question in (64) can be answered by $(64 a-c),(a-b)$ representing SFF. However, quantifier stranding like in (64a) is not possible if the (infinitival) VP is fronted as in (64d), in contrast to German (see (65b)).

\section{What else could I do?}
a. RŮží bys mohl pár koupit.
roses.gen aux.2sg could.sg.ms a-few buy.inf
'You could buy a few roses.'
b. [pár RŮží $]_{i}$ bys mohl koupit $t_{i}$. a-few roses.gen aux.2sg could.sg.ms buy.inf
c. [Koupit pár RŮží $]_{i}$ bys mohl ti buy.inf a-few roses.gen aux.2sg could.sg.ms

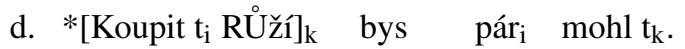 buy roses.gen aux.2sg a-few could.sg.ms

(65) What else could I do?

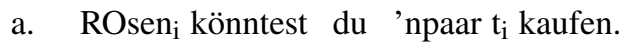
roses could.2sg you a-few buy.inf

b. [ROsen $t_{i}$ kaufen $]_{k}$ könntest du 'npaar $t_{k}$.

\subsubsection{SFF is not scattered deletion}

As pointed out by a reviewer, a related possibility of explaining SFF in terms of focusfeature checking consists of scattered deletion (Bošković 2002; Fanselow and Ćavar 2002). If the deletion following copying can affect both copies, SFF constructions could involve focus phrases in which all material but the leftmost accented XP has been deleted in the left copy, with the remainder being realized in the right copy, as in (66).

A: What did he do?

B: [Ein BUCH zerrissen] hat er [ein BUCH zerrissen].

$$
\text { a book torn up has he a book torn up }
$$

'He tore up a book.' 
Scattered deletion is, however, no improvement over remnant movement with respect to the parasitic gap argument and the subject-definiteness problem. The locality differences between partial VP-fronting and SFF movement also find no satisfactory explanation. Furthermore, scattered deletion has been introduced for discontinuous DPs and PPs, and does not always yield SFF-like results in this context. Czech allows discontinuous DPs in answers to discontinuous $w h$-phrases like 'whose- $\mathrm{X}$ ' and 'what kind of-X', as in (67a), although pied-piping of the whole DP is a valid option, as in (67b) (as well as leaving the DP in situ-(67c)):
Q: Jakou jí koupil růži? what.acc her.dat bought.sg.ms rose.acc
'What kind of a rose did he buy her?'
a. ČERvenou jí koupil růži.
red.acc her.dat bought.sg.ms rose.acc
'He bought her a red rose.'
b. ČERvenou růži jí koupil.
c. Koupil jí ČERvenou růži.

In (67), the wh-word imposes a narrow focus reading on the fronted modifier in the answer, whereas the part of the noun phrase stranded in (67a) belongs to the background. Note, however, that structures like (67a) are infelicitous in contexts like (68), with Q1 imposing DP-focus and Q2 VP/IP-focus.

\section{Q1: Karel invited Hana to the cinema and Jan brought her a white rose. What did Emil buy? \\ Q2: Peter invited Hana to the cinema and John brought her a white rose. What did Emil do/ What did Emil buy?}
a. \#ČERvenou jí koupil růži. red.acc her.dat bought.sg.ms rose.acc
b. ČERvenou růži jí koupil.
c. Koupil jí ČERvenou růži.

The contrast between (67) and (68) could be explained if the upstairs deletion may apply only to parts that do not belong to the focused phrase. Then even the deaccented noun rose in the answers of (68) would resist deletion, being part of the focused phrase. But note that such a rule would exclude felicitous cases of SFF. For example, the example in (13c), discussed in Sect. 3 and repeated in (69), should be impossible, due to the deletion of a part of the focus upstairs. ${ }^{40}$

\footnotetext{
${ }^{40}$ The difference between (67) and (68) is also relevant for a potential remnant movement analysis of SFF. Left-branch extractions like (67a) have been analyzed as movement of a DP-remnant, cf. Corver (1990). As the parallel SFF example in (68a) is ungrammatical, we would have to postulate different kinds of remnant movement for the two phenomena.
} 
What have you bought?

KNÍžek $_{\mathrm{i}}$ jsem si [pár $\mathrm{t}_{\mathrm{i}}$ ] koupil.

book.gen.pl aux.1sg refl. a-few bought.sg.ms

\section{Eliminating focus and topic movement?}

In the preceding sections, we have argued that LP-movement in Czech, German, and other languages is triggered by an unspecific edge feature of $\mathrm{C}$. Movement is not restricted by the MLC (Chomsky 2008). From the unspecific nature of the edge feature of $\mathrm{C}$, it follows that XPs need not bear any pragmatic function in order to be allowed into SpecCP. The absence of a minimal link constraint also allows that movement to SpecCP originates in any structural position as long as this is compatible with the phase theory. We have shown that certain construction types (SFF and FF constructions, complemented by some remarks on subpart of topic fronting) fit into this picture. If anything can be attracted by the unspecific edge feature of $\mathrm{C}$, so can topics and foci, which makes specific processes for topic or focus movement superfluous.

The elimination of topic and focus movement from grammar presupposes at least three further steps, however: we must show that our model allows all and only pragmatically appropriate choices of the categories moved to the left periphery (6.1), that binding and scope facts often linked to discourse status come out correctly (6.2), and that differences in locality and intervention effects between various descriptive classes of movement come out correctly (6.3). We will turn to these questions now.

\subsection{Topic vs. focus: Size of the fronted category}

A focus or a topic movement rule displaces exactly the focus or the topic of an utterance. The movement triggered by an edge feature of Comp is unselective in this respect. The fronted XP may happen to be the focus or the topic, but it can also be a smaller or larger category, as we argued in Sect. 3.

Given the unspecific nature of the edge feature of $\mathrm{C}$, we expect that a category larger than the focus can be fronted, too. This prediction is borne out: a question imposing a narrow focus on the direct object is also congruent with (70b), a sentence in which the VP dominating the focused direct object has been moved. (71) shows that a DP can move to the left periphery if it contains the focus.

What have you bought?

a. $\quad[\text { Ein BUCH }]_{i}$ hab' ich mir $t_{i}$ gekauft. a book have I myself bought

b. [vp Ein BUCH gekauft $]_{\mathrm{i}}$ hab' ich mir $\mathrm{t}_{\mathrm{i}}{ }^{41}$ 'I bought a book.'

\footnotetext{
${ }^{41}$ The fronted constituent in (70b) cannot serve as term answer in the same dialogue, cf. (i). This is expected if we analyse term answers as sentential answers, in which the string identical with the congruent $w h$-phrases has been deleted (e.g., Reich 2003). The string is identical only in (ib).
} 
Have you read a book about Poland?

Nein. [Ein Buch über INDIEN] $]_{i}$ habe ich $t_{i}$ gelesen.

no a book about India have I read

'No. I have read a book about India.'

That a category larger than the focus can go to SpecCP is, as such, not surprising. After all, the focus XP may be trapped in an island so that it cannot be fronted. In such constellations, pied-piping is often an option.

Whose book have you bought?

a. [Obamas Buch $]_{i}$ hab' ich ti gekauft.

Obamas book have I bought

b. *Obamas hab' ich Buch gekauft.

There is, however, a restriction on pied-piping that implies that examples such as (70) and (71) cannot be the result of pied-piping in the context of the attraction of a focus feature. As Heck (2004) shows, if $\alpha$ is attracted to $\beta$, a $\Gamma$ c-commanded by $\beta$ and dominating $\alpha$ can be pied-piped only if $\alpha$ (or a category $\mathrm{D}$ dominating $\alpha$ and dominated by $\Gamma$ ) cannot be extracted from $\Gamma$. In other words, pied-piping is restricted to categories that are syntactic islands for the attracted category. Consequently, a DP can be pied-piped when its $w h$-specifier is attracted, because German does not allow violations of the left branch condition (72b).

$\mathrm{VP}$, however, is not a barrier for movement, and cannot be pied-piped. Likewise, DPs are not barriers for the extraction of PPs. (73) shows that a DP containing a PP and a VP containing a DP cannot be pied-piped when the underlined category is attracted because of its $w h$-feature. Therefore (70b) and (71) can hardly be explained in terms of focus attraction and pied-piping. ${ }^{42}$

I do not care...

a. $\quad \ldots$ wessen Buch du kaufst.

whose book you buy

b. *... ein Buch über wen du kaufst

a book about who you buy

c. *...was gekauft du hast

what bought you have

(i) Was hast du gekauft? What have you bought?

a. *Ein BUCH gekauft.

b. Ein Buch habe ich gekauft.

${ }^{42}$ The degraded status of (ia) shows that the prosodic integration of the verb plays a crucial role in determining the status of (70b) and (ib). Syntactically, there is no major difference between these sentences, but prosodically, there is: the verb integrates into the phonological phrase of the direct object, but the indirect object does not, and if it would, the resulting phonological object would not have the strongest accent at its left edge.

(i) What did you give to Mary?

a. ? Der Maria ein Buch geschenkt habe ich.

the.dat Mary a book presented have I

'I presented Mary with a book.'

b. Ein Buch geschenkt hab' ich der Maria.

a book presented have I the Mary 
Horvath (2007) observes similar facts for Hungarian, and interprets them as an argument against the triggering of movement by a focus feature.

Let us now consider topic movement. Topics can optionally move to SpecCP, and (contrastive) topic fronting can be partial. In these respects, topics and foci behave alike. However, it is difficult to place an element containing a topic into SpecCP, apart from instances of obligatory pied-piping. This is illustrated in (74) by the inappropriateness of fronting a VP containing a direct object topic observed by Frey (2004).

$$
\begin{aligned}
& \text { What about Tom? } \\
& \text { a. Den }{ }_{i} \text { hat niemand } t_{i} \text { eingeladen. } \\
& \text { him has nobody invited } \\
& \text { b. \#[VP den eingeladen] hat niemand tVP. } \\
& \text { 'Nobody invited him.' } \\
& \text { c. \#[VP den Idioten eingeladen] hat niemand tVP. } \\
& \text { the.acc idiot invited has nobody } \\
& \text { 'Nobody invited that idiot.' }
\end{aligned}
$$

However, German topics seem to always leave VP (Frey 2004), consequently, a fronted VP cannot carry along the topic. TPs, on the other hand, arguably cannot be moved to SpecCP (Wurmbrand 2001). The data in (74) thus find an independent explanation. If this is correct, one predicts that a fronted subordinate $\mathrm{CP}$ can contain a topic, and this prediction is borne out. The co-occurrence of ( $75 b)$ and $\left(75 b^{\prime}\right)$ shows that the topic can go along with the rest of $\mathrm{CP}$ in contexts where it could itself be extracted, i.e., (75b) is not amenable to a pied-piping analysis.

$$
\begin{aligned}
& \text { a. As for your book, } \\
& \text { [CP das lesen zu müssen] war eine Zumutung. } \\
& \text { that read to must was a cheek } \\
& \text { 'It was a bit too much to have to read it.' } \\
& \text { b. As for generative syntax, } \\
& \text { die zu unterrichten ist mir ein Gräuel. } \\
& \text { it to teach is me.dat a horror } \\
& \text { 'I hate teaching generative syntax.' } \\
& \text { b'. die ist mir zu unterrichten ein Gräuel. }
\end{aligned}
$$

LP-movement thus turns out to not be adequately describable in terms of pragmatic features: what goes to SpecCP may be smaller, larger, or identical with the focus and the topic, and neither the topic nor the focus have to undergo LP-movement at all.

\subsection{Topic vs. focus: Binding and reconstruction}

A further difference between the descriptive types of LP-movement lies in an observation we owe to one of the anonymous reviewers: the fact that (76a) allows, whereas (76b) disallows, a bound interpretation, suggests that focus movement undergoes obligatory reconstruction at LF (note that (76a) is a case of SFF). On the 
other hand, the fronted phrase in (76c) may take scope over the focused phrase that it moved across. ${ }^{43}$ Does that constitute a good reason for distinguishing different types of LP-movement syntactically?
a. What did the trainer say after they got kicked out of the tournament?

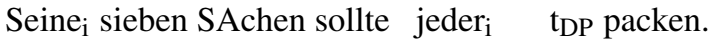
his seven things should everyone pack
'Everybody should leave.'
b. *Jedes ${ }_{\mathrm{i}}$ ZImmer sollte $\operatorname{sein}_{\mathrm{i}}$ Bewohner $\mathrm{t}_{\mathrm{DP}}$ aufräumen.
every room should its inhabitant clean up.
'Every room should be cleaned up by its inhabitant.'

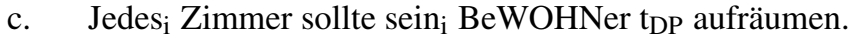

SpecCP is an A-bar position and therefore irrelevant for the A-binding of pronouns. Therefore, the creation of new binding options in contexts such as (76c) rather than the need for reconstruction in (76b) (which one expects for A-barmovement) is the remarkable property. Haider (1981) proposed that 'new' binding options of XPs in SpecCP are established before the phrase moves to SpecCP. In current terms, this means that new binding options are due to an intermediate derivational step (e.g., scrambling) that has properties of A-movement (Fanselow 2001; Haider and Rosengren 2003; Frey 2004). This explains the differences in (76). Phrases cannot scramble when they have a structural accent, because their linearization would then be fixed when they are merged. If a phrase with a structural accent moves to SpecCP, it therefore cannot have undertaken an intermediate scrambling step. Thus, the movement step necessary for yielding a new binding option cannot be carried out. LP-movement displacing part of a focus thus always reconstructs semantically, which explains $(76 a \& b)$. If a phrase has no structural accent it can be scrambled and mapped to SpecCP subsequently. From this scrambled position, new binding options can be created (e.g., an object binding a pronoun in a subject), which further movement to SpecCP does not destroy (76c). The difference between the various instances of movement to SpecCP with respect to binding are thus predicted in our model.

\section{Crosslinguistic remarks}

In the theory proposed here, LP-movement is constrained by phase theory and the intervention effects due to EA and immediate linearization resulting from accentuation. The latter aspect implies the existence of at least three different types of languages. ${ }^{44}$

\footnotetext{
${ }^{43}$ Czech behaves the same with respect to this point, but we will only discuss the German example provided to us by the anonymous reviewer.

${ }^{44}$ Thanks go to Konstantin Kazenin (Russian, tested in a linguistics class at Moscow University); Tijana Ašić, Damir Ćavar, Luka Szucsich (Serbian/Croatian); Joanna Błaszczak, Pawel Rutkowski (Polish); Andrej Stopar (Slovenian), Hans Broekhuis, Norbert Corver, Ruben van de Vijver (Dutch); Elisabeth Engdahl, Christer Platzack (Swedish); Stavros Skopeteas (Greek); Kaja Kohler (Estonian), and Henna Kairanneva (Finnish).
} 
EA effects come out most clearly in languages in which XPs in argument positions may but need not bear a structural accent. Whether XPs exert intervention effects for other phrases moving to the left periphery then depends on the presence or absence of a structural accent. We have discussed this in detail for German and Czech, and would like to note here that further languages with in situ deaccentuation possibilities show the same behavior. (77) illustrates SFF movement across a deaccented subject in Russian.

$$
\begin{aligned}
& \text { What have the children done? } \\
& \text { Cvety } \mathrm{i}_{\mathrm{i}} \text { oni sobrali } \mathrm{t}_{\mathrm{i}} \text {. } \\
& \text { flowers.acc they plucked.pl } \\
& \text { 'They have plucked flowers.' }
\end{aligned}
$$

Likewise, Polish, Slovenian, Serbian-Croatian, and Dutch and Swedish possess SFF. $^{45}$ In Greek, the accented part of an idiom can also be preposed without a loss of the idiomatic interpretation, cf. (78).

$$
\begin{aligned}
& \text { What about the neighbours? } \\
& \text { Mijes varane i jítones. (Greek, S. Skopeteas, p.c.) } \\
& \text { fly.acc.pl hit.3pl def.nom.pl.ms neighbour.nom.pl.ms } \\
& \text { 'The neighbors are bored.' }
\end{aligned}
$$

English seems to pattern with German and Czech, too, but not for leftward movement. According to Williams (2003: 34) instances of English Heavy NP-Shift can figure as a reply in (79). We concur with Williams' claim that the moved bracketed constituent is part of the focus, not the focus, and in that respect, the construction resembles SFF.

What did John do?

John gave to Mary [all of the money in the satchel].

As noted in Sect. 5.1, SFF constructions exist also in Haitian Creole, Hausa, and Gurune. They exemplify a second type of languages, in which structurally accented phrases receive their stress after movement to the left periphery, so that no intervention effects due to EA can be observed.

EA is inoperative also in Hungarian. Szendrői (2001) claims for Hungarian that an XP moves to the preverbal 'focus' position in order to pick up stress there. The movement to the focus position thus does not start in a slot in which a structural accent is assigned, rather, it terminates there. Consequently, there can be no intervention effects. At the same time, the movement to the preverbal position may affect a subpart of the focus (e.g., Kenesei 1998). (80) illustrates SFF with an idiomatic ex-

\footnotetext{
${ }^{45}$ According to our Serbian/Croatian informants, the fronting of a direct object in case of a VP- or IPfocus is linked to the expression of annoyance. Such an additional effect is absent with the narrow focus interpretation of fronted direct objects. It is difficult if not impossible to pack such usage differences in the syntactic derivation. Ideally this can be linked to sociolinguistic or stylistic conditions of use. In Dutch and Swedish, SFF constructions are rather marked (as compared to narrow focus object fronting). This could be linked to conditions of use as well.
} 
pression: according to I. Kenesei (p.c.), both linearizations are possible with a wide focus reading as long as both NPs are stressed. ${ }^{46}$

a. Anna a gombhoz varrta a kabátot.

(Hungarian, I. Kenesei, p.c.)

Anna the button.all sewed the coat.acc

b. Anna a kabátot varrta a gombhoz.

Anna the coat.acc sewed the button.all

'Anna sewed the coat to (fit) the button.'

$=$ 'She was attentive to the details rather than the whole picture.'

Hungarian thus confirms the expectation that the intervention effects with SFF arise only in languages with early accentuation, but more work is needed for establishing a firm typological connection between prosody and movement constraints.

Italian (It) represents a third type of languages. It differs from German and Czech in that in situ deaccentuation of lexical NPs as we find it in Germanic or Slavic is absent. ${ }^{47}$ We expect this to have an influence on movement to the left periphery, and the predictions of our model indeed seem to be borne out.

Recall that Rizzi (1997) argued on the basis of Italian data that focus and topic movement differ syntactically. In contrast to topic fronting, focus fronting shows weak crossover effects and does not involve clitic doubling.

There is nothing unexpected in the focus data: weak crossover is typical of A-barmovement in languages without scrambling, and foci cannot be linked to clitics in situ either. Furthermore, (81) illustrates that Italian allows SFF, too: the accented part of an idiom has moved into the 'focus' position. This parallel between German/Czech and Italian suggests that 'focus' fronting is effected by an unspecific edge feature of Comp in Italian, too.

What have you done to the pig?

La festa, gli abbiamo fatto.

the feast, to-him have.1pl done

(It, V. Samek-Lodovici, p.c.)

'We killed him.'

Note now that there is a ban against overt non-pronominal subjects in SpecTP that characterizes various constructions in Italian, viz. wh-movement/focus movement, see (82) and resumptive preposing of aboutness topics (Cardinaletti 2002; Cinque 1990), or left peripheral focus in Sicilian (Cruschina 2006).
a. * Chi Gianni ha invitato? who Gianna has invited
b. * A MARIA Gianni parlò no na Paolo. to Mary Gianni talked not to Paul

\footnotetext{
${ }^{46}$ There are of course further facts to be accounted for, see Horvath (2007) among others. For example, the subject must be moved to preverbal position in wide focus contexts when it is neither pronominal nor a topic, as pointed out by I. Kenesei (p.c.). A detailed treatment of Hungarian is beyond the scope of this paper.

${ }^{47}$ There is, however, a postfocal operation of 'marginalization', cf. Antinucci and Cinque (1977).
} 
These operations can only apply across empty or weak pronominal subjects, or across traces of heavy NP-shift. This restriction seems to follow directly from the absence of in situ deaccentuation: in particular, non-pronominal subjects are immediately linearized when they are placed into SpecTP. The blocking effect of intervening lexical subjects for the constructions in (81) and (82) is therefore, in principle, amenable to a treatment in terms of linearization theory that excludes the movement of structurally accented categories past an XP that has been serialized.

One way of understanding the Italian topic data could thus be related to the idea that XPs are immediately serialized and equipped with structural accents in TP. Topics bearing a non-structural accent thus need to be merged outside TP, i.e., a construction such as CLLD has to be chosen. By and large, Italian fits well into the model proposed here, but the absence of in situ deaccentuation forces a non-movement origin for topics in most contexts.

\section{Concluding remarks}

In descriptive terms, the choice of a marked word order goes hand in hand with the expression of a marked information structure in many languages. That such correlations of form and function are reflected in the mechanics of syntax may seem very plausible, but we have shown that theories of this sort do not capture the wealth of empirical facts in languages with free constituent order. For the languages we have considered, it seems safe to conclude that notions of information structure play no role in determining what is fronted to the left periphery of a clause, and they neither figure in determining the locality of fronting nor in any other syntactically relevant aspect of the construction. Movement to the left periphery is triggered by an unspecific edge feature of Comp, and the choice of the category to be fronted is arbitrary from a syntactic point of view. This finding is in line with the observation that constructions do not have a uniform function in natural language. Thus, Baker (2001) points out that Mohawk sentences have the syntactic structure of Italian clitic left dislocation constructions without sharing their pragmatic force.

The conclusion we draw is that notions of information structure play no role in the functioning of syntax (see also Chomsky 2008). Focus features/focus marking was added to syntactic representation in the past when the Government\&Binding architecture of syntax had no direct means of transporting information from the PFrepresentation of a clause to its LF, and vice versa (see Horvath 2007 for a lucid reconstruction of the history of focus marking in the syntax). More recent syntactic models allow for a parallel computation of prosodic, semantic and syntactic properties of a sentence, so they need no 'mediating' features. There is no reason left for coding information structure in the syntactic representation, and our results show that there is also no empirical motivation for it.

Prosody is the primary means of expressing information structure. There can be no doubt that prosody has an influence on the well-formedness of syntactic representations. We have proposed that this influence is effected in an indirect way, too: prosodic structure is computed on the basis of linearization information, and linearization is a crucial factor in determining syntactic locality (Fox and Pesetsky 2005; Müller 2007). 
Acknowledgements The research reported here was partially supported by grants of the German Research Foundation FOR 375 (A3), SFB 632 (A1, C1) [Potsdam]; and FOR 349 (D1), FOR 742 (P4) [Leipzig/Göttingen]. Numerous discussions with our colleagues have helped us to improve the present paper considerably. In particular, we are indebted to Joanna Błaszczak, Caroline Féry, Werner Frey, HansMartin Gärtner, Beáta Gyuris, Andreas Haida, Daniel Hole, Roland Hinterhölzl, Shin Ishihara, István Kenesei, Katalin É. Kiss, Ivona Kučerová, Maria Lesinski, Roland Meyer, Gereon Müller, Stefan Müller, Andreas Pankau, David Pesetsky, Pawel Rutkowski, Vieri Samek-Lodovici, Matthias Schlesewsky, Stefan Sudhoff, Tue Trinh, and Malte Zimmermann. Our thanks also go to the four anonymous reviewers and Marcel den Dikken for their very helpful comments and suggestions, and to the participants of various workshops and lectures in Berlin, Gniezno, Leipzig, London, Stuttgart, and Warsaw.

Open Access This article is distributed under the terms of the Creative Commons Attribution Noncommercial License which permits any noncommercial use, distribution, and reproduction in any medium, provided the original author(s) and source are credited.

\section{References}

Adger, David. 2007. Stress and phasal syntax. Linguistic Analysis 33: 238-266.

Alboiu, Gabriela. 2004. Optionality at the interface: Triggering focus in Romanian. In Triggers, eds. Henk van Riemsdijk and Anne Breitbath, 49-75. Berlin: Mouton de Gruyter.

Antinucci, Francesco, and Guglielmo Cinque. 1977. Sull'ordine delle parole in Italiano: l'emarginazione. Studi di Grammatica Italiana 6: 121-146.

Baker, Mark. 2001. The natures of non-configurationality. In Handbook of syntax, eds. Mark Baltin and Chris Collins, 407-438. Oxford: Blackwell.

Bayer, Josef, and Jaklin Kornfilt. 1994. Against scrambling as an instance of move alpha. In Studies on scrambling, eds. Henk van Riemsdijk and Norbert Corver, 17-60. Berlin: Mouton de Gruyter.

Bošković, Željko. 2002. Clitics as non-branching elements and the Linear Correspondence Axiom. Linguistic Inquiry 33: 329-340.

Bresnan, Joan. 1972. Stress and syntax: A reply. Language 48: 326-342.

Büring, Daniel. 1997. The meaning of topic and Focus. The 59th street bridge accent. London: Routledge.

Büring, Daniel. 2006. Focus projection and default prominence. In The architecture of focus, eds. Valéria Molnár and Susanne Winkler, 321-346. Berlin: Mouton de Gruyter.

Büring, Daniel. 2007. Semantics, intonation and information structure. In The Oxford handbook of linguistic interfaces, eds. Gillian Ramchand and Charles Reiss, 445-474. Oxford: Oxford University Press.

Cardinaletti, Anna. 2002. Against optional and zero clitics. Right dislocation vs. marginalization. Studia Linguistica 56: 29-57.

Chomsky, Noam. 1981. Lectures on government and binding. Dordrecht: Foris.

Chomsky, Noam. 1995. The minimalist program. Cambridge: MIT Press.

Chomsky, Noam. 2008. On phases. In Foundational issues in linguistic theory: Essays in honor of JeanRoger Vergnaud, eds. Robert Freidin, Carlos P. Otero, and Maria Luisa Zubizarreta, 133-166. Cambridge: MIT Press.

Cinque, Guglielmo. 1990. Types of $A^{\prime}$-dependencies. Cambridge: MIT Press.

Corver, Norbert. 1990. The syntax of left branch extractions. PhD dissertation, Katholieke Universiteit, Brabant.

Cozier, Franz. 2006. The co-occurrence of predicate clefting and $w h$-phrasess in Trinidad dialectal English. Natural Language \& Linguistic Theory 24 (3): 655-688.

Cruschina, Silvio. 2006. Informational focus in Sicilian and the left periphery. In Phases of interpretation, ed. Mara Frascarelli, 363-385. Berlin: Mouton de Gruyter.

den Dikken, Marcel. 2006. Relators and linkers: The syntax of predication, predicate inversion, and copulas. Cambridge: MIT Press.

Diesing, Molly. 1990. The syntactic roots of semantic partition. PhD dissertation, University of Massachusetts, Amherst.

Engels, Eva. 2004. Adverb placement. An optimality theoretic approach. PhD dissertation, Universität Potsdam, Germany. 
Epstein, Samuel D., and T. Daniel Seely. 2002. Rule applications as cycles in a level-free syntax. In Derivation and explanation in the minimalist program, eds. Samuel D. Epstein and T. Daniel Seely, 65-89. Oxford: Blackwell.

Ernst, Thomas. 2002. The syntax of adjuncts. Cambridge: Cambridge University Press.

Fanselow, Gisbert. 1993. The return of base generators. Groninger Arbeiten zur Germanistischen Linguistik 36: 1-74.

Fanselow, Gisbert. 2001. Features, $\theta$-roles, and free constituent order. Linguistic Inquiry 32 (3): $405-437$.

Fanselow, Gisbert. 2002. Quirky subjects and other specifiers. In More than words, eds. Ingrid Kaufmann and Barbara Stiebels, 227-250. Berlin: Akademie Verlag.

Fanselow, Gisbert. 2004. Cyclic phonology-syntax interaction: Movement to first position in German. In Working papers of the SFB 632. Interdisciplinary studies on information structure 1, eds. Shinichiro Ishihara and Michaela Schmitz, 1-42. Potsdam: Universitätsverlag.

Fanselow, Gisbert. 2010. Scrambling as formal movement. In Information structure: Contrasts and positions, eds. Ad Neeleman and Ivona Kučerová. Cambridge: Cambridge University Press (in press).

Fanselow, Gisbert, and Damir Ćavar. 2002. Distributed deletion. In Theoretical approaches to universals, ed. Artemis Alexiadou, 65-107. Amsterdam: John Benjamins.

Fanselow, Gisbert, Denisa Lenertová, and Thomas Weskott. 2008. Studies on the acceptability of object movement to Spec, CP. In The discourse potential of underspecified structures, ed. Anita Steube, 413-438. Berlin: Mouton de Gruyter.

Féry, Caroline, and Heiner Drenhaus. 2008. Single prosodic phrase sentences. In Working papers of the SFB 632. Interdisciplinary studies on information structure 10, eds. Shinichiro Ishihara, Svetlana Petrova, and Anne Schwarz, 1-44. Potsdam: Universitätsverlag.

Féry, Caroline, and Shinichiro Ishihara. 2009. The phonology of Second Occurrence Focus. Journal of Linguistics 45 (2): 285-313.

Féry, Caroline, and Frank Kügler. 2008. Pitch accent scaling on given, new and focused constituents in German. Journal of Phonetics 36 (4): 680-703.

Féry, Caroline, and Vieri Samek-Lodovici. 2006. Focus projection and prosodic prominence in nested foci. Language 82 (1): 131-150.

Fox, Danny, and David Pesetsky. 2005. Cyclic linearization and its interaction with other aspects of grammar. Theoretical Linguistics 31: 235-262.

Franks, Steven, and Tracy H. King. 2000. A handbook of Slavic clitics. Oxford: Oxford University Press.

Frey, Werner. 2004. A medial topic position for German. Linguistische Berichte 198: 153-190.

Frey, Werner. 2005. Zur Syntax der linken Peripherie im Deutschen. In Deutsche Syntax: Empirie und Theorie, ed. Franz Josef d'Avis, 147-171. Göteborg.

Grewendorf, Günther. 1980. Funktionale Satzperspektive und deutsche Wortstellung. Linguistische Berichte 66: 28-40.

Haider, Hubert. 1981. Empty categories. On some differences between English and German. Wiener Linguistische Gazette 25: 13-36.

Haider, Hubert. 1990. Topicalization and other puzzles of German syntax. In Scrambling and barriers, eds. Günther Grewendorf and Wolfgang Sternefeld, 93-112. Amsterdam: John Benjamins.

Haider, Hubert, and Inger Rosengren. 2003. Scrambling: Non-triggered chain formation in OV languages. Journal of Germanic Linguistics 15: 203-267.

Halle, Morris, and Alec Marantz. 1993. Distributed morphology and the pieces of inflection. In The view from building 20, eds. Kenneth Hale and Samuel Jay Keyser, 111-176. Cambridge: MIT Press.

Hartmann, Katharina, and Malte Zimmermann. 2007. In place-out of place: Focus in Hausa. In On information structure, meaning and form: Generalizations across languages, eds. Kerstin Schwabe and Susanne Winkler, 365-403. Amsterdam: John Benjamins.

Heck, Fabian. 2004. A theory of pied-piping. PhD dissertation, Universität Tübingen, Germany.

Höhle, Tilman. 1979. 'Normalbetonung' und 'Normale Wortstellung': eine pragmatische Explikation. Leuvense Bijdragen 66: 385-437.

Holmberg, Anders. 2000. Scandinavian stylistic fronting: How any category can become expletive. Linguistic Inquiry 31 (3): 445-483.

Horn, George. 2003. Idioms, metaphors and syntactic mobility. Journal of Linguistics 39: 245-273.

Horvath, Julia. 2007. Separating focus movement from focus. In Phrasal and clausal architecture: Syntactic derivation and interpretation, eds. Simin Karimi, Vida Samiian, and Wendy K. Wilkins, 108-145. Amsterdam: John Benjamins.

Ishihara, Shinichiro. 2007. Major phrase, focus intonation, multiple spell-out. The Linguistic Review 24 (2-3): 137-167. 
Jackendoff, Ray. 1972. Semantic interpretation in generative grammar. Cambridge: MIT Press.

Jacobs, Joachim. 1991. Focus ambiguities. Journal of Semantics 8: 1-36.

Jacobs, Joachim. 1996. Bemerkungen zur I-Topikalisierung. Sprache und Pragmatik 41: 1-48.

Jacobs, Joachim. 1999. Informational autonomy. In Focus: Linguistic, cognitive, and computational perspectives, eds. Peter Bosch and Robert van der Sandt, 56-81. Cambridge: Cambridge University Press.

Kahnemuyipour, Arsalan. 2004. The syntax of sentential stress. PhD dissertation, University of Toronto, Toronto.

Kathol, Andreas. 2001. On the nonexistence of true parasitic gaps in standard German. In Parasitic gaps, eds. Peter W. Culicover and Paul M. Postal, 315-338. Cambridge: MIT Press.

Kenesei, István. 1998. Adjuncts and arguments in VP-focus in Hungarian. Acta Linguistica Hungarica 45: 61-88.

Kiss, Katalin É.. 1998. Identificational focus and information focus. Language 74: 245-273.

Kratzer, Angelika, and Elisabeth Selkirk. 2007. Default phrase stress, prosodic phrasing and the spellout edge. The Linguistic Review 24: 93-135.

Krifka, Manfred. 1994. Focus and operator scope in German. In Proceedings of the conference on focus and natural language processing, eds. Peter Bosch and Robert van der Sandt, 133-152. Heidelberg: IBM Scientific Centre.

Krifka, Manfred. 2006. Association with focus phrases. In The architecture of focus, eds. Valéria Molnár and Susanne Winkler, 105-136. Berlin: Mouton de Gruyter.

Kučerová, Ivona. 2005. The T-extension condition. In Proceedings of the 24th west coast conference on formal linguistics, eds. John Alderete, Han Chung-hye, and Alexei Kochetov, 227-235. Somerville: Cascadilla Press.

Kučerová, Ivona. 2007. The syntax of givenness. PhD dissertation, MIT, Massachusetts.

Kvam, Sigmund. 1983. Linksverschachtelung im Deutschen und Norwegischen: eine kontrastive Untersuchung zur Satzverschränkung und Infinitivverschränkung in der deutschen und norwegischen Gegenwartssprache. Tübingen: Niemeyer.

Ladd, D. Robert. 1996. Intonational phonology. Cambridge: Cambridge University Press.

Lenertová, Denisa. 2004. Czech pronominal clitics. Journal of Slavic Linguistics 12: 139-176.

Lenertová, Denisa, and Uwe Junghanns. 2007. Fronted focus exponents with maximal focus interpretation in Czech. In On information structure, meaning and form: Generalizations across languages, eds. Kerstin Schwabe and Susanne Winkler, 347-363. Amsterdam: John Benjamins.

Meyer, Roland. 2004. Syntax der Ergänzungsfrage: Empirische Untersuchungen am Russischen, Polnischen und Tschechischen. München: Sagner.

Müller, Gereon. 1998. Incomplete category fronting. Kluwer: Dordrecht.

Müller, Gereon. 2004. Verb second as vP first. The Journal of Comparative Germanic Linguistics 7 (3): 179-234.

Müller, Gereon. 2007. Towards a relativized concept of cyclic linearization. In Interfaces + recursion = language? Chomsky's minimalism and the view from syntax-semantics, eds. Uli Sauerland and Hans-Martin Gärtner, 61-114. Berlin: Mouton de Gruyter.

Müller, Gereon, and Wolfgang Sternefeld. 1993. Improper movement and unambiguous binding. Linguistic Inquiry 24: 461-507.

Müller, Gereon, and Wolfgang Sternefeld. 1996. A-bar chain formation and economy. Linguistic Inquiry 27: 480-511.

Müller, Stefan. 2003. Mehrfache Vorfeldbesetzung. Deutsche Sprache 31: 29-62.

Neeleman, Ad, and Kriszta Szendrői. 2004. Superman sentences. Linguistic Inquiry 35: 149-159.

Neeleman, Ad, and Hans van de Koot. 2008. Dutch scrambling and the nature of discourse templates. The Journal of Comparative Germanic linguistics 11 (2): 137-189.

Newman, Paul. 2000. The Hausa language: An encyclopedic reference grammar. New Haven: Yale University Press.

Nunberg, Geoffrey, Ivan Sag, and Thomas Wasow. 1994. Idioms. Language 70: 491-538.

Puig-Waldmüller, Estela. 2006. Wörter stehen da einige. On nominal split constructions in non standard Viennese German. Baccalaureate dissertation, Universitat Pompeu Fabra, Barcelona.

Reich, Ingo. 2003. Frage, Antwort und Fokus. Berlin: Akademie Verlag.

Reinhart, Tanya. 1981. Pragmatics and linguistics: An analysis of sentence topics. Philosophica 27: 6394.

Rizzi, Luigi. 1991. Residual verb second and the wh-criterion. Technical Report 3, Geneva.

Rizzi, Luigi. 1997. The fine structure of the left-periphery. In Elements of grammar: Handbook of generative syntax, ed. Liliane Haegeman, 281-337. Dordrecht: Kluwer. 
Roberts, Ian. 1993. Verbs and Diachronic Syntax. Reidel: Dordrecht.

Rochemont, Michael. 1986. Focus in generative grammar. Philadelphia: John Benjamins.

Rooth, Mats. 1996. Focus. In Handbook of contemporary semantic theory, ed. Shalom Lappin, 271-296. Oxford: Oxford University Press.

Schwarzschild, Roger. 1999. GIVENness, AvoidF and other constraints on the placement of accent. Natural Language Semantics 7 (2): 141-177.

Selkirk, Elisabeth. 1995. Sentence prosody: Intonation, stress, and phrasing. In The handbook of phonological theory, ed. John A. Goldsmith, 550-569. Cambridge: Blackwell.

Szendrôi, Kriszta. 2001. Focus and the syntax-phonology interface. $\mathrm{PhD}$ dissertation, University College London, London.

Svollacchia, Marco, Lunella Mereu, and Annarita Puglielli. 1995. Aspects of discourse configurationality in Somali. In Discourse configurational languages, ed. Katalin É. Kiss, 65-98. Oxford: Oxford University Press.

Thiersch, Craig. 1978. Topics in German syntax. PhD dissertation, MIT, Massachusetts.

Toman, Jindřich. 1999. On clitic displacement. In Topics in south Slavic syntax and semantics, eds. Mila Dimitrova-Vulchanova and Lars Hellan, 205-228. Amsterdam: John Benjamins.

Travis, Lisa. 1984. Parameters and effects of word order variation. PhD dissertation, MIT, Massachusetts.

Truckenbrodt, Hubert. 2004. Final lowering in non-final position. Journal of Phonetics 32: 313-348.

Truckenbrodt, Hubert. 2007. The syntax-phonology interface. In The Cambridge handbook of phonology, ed. Paul de Lacy, 435-456. Cambridge: Cambridge University Press.

van Craenenbroek, Jeroen, and Liliane Haegeman. 2007. The Derivation of subject initial V2. Linguistic Inquiry 38: 167-178.

van Hoof, Hanneke, 2003. The rise in the rise-fall contour: Does it evoke a contrastive topic or a contrastive focus? Linguistics 41 (3): 515-563.

Wagner, Michael. 2005. Asymmetries in prosodic domain formation. MIT Working Papers in Linguistics 49: 329-367.

Wagner, Michael. 2006. Association by movement: evidence from NPI-licensing. Natural Language Semantics 14 (4): 297-324.

Walker, Marilyn, Aravind K. Joshi, and Ellen Prince. 1998. Centering theory in the discourse. Oxford: Oxford University Press.

Williams, Edwin. 2003. Representation theory. Cambridge: MIT Press.

Wurmbrand, Susi. 2001. AGREE_-The other VP-internal subject hypothesis. In Proceedings of the 20th west coast conference on formal linguistics, eds. Karine Megerdoomian and Leora Ann Bar-el, 635648. Somerville: Cascadilla Press.

Zubizarreta, Maria Luisa. 1998. Prosody, focus and word order. Cambridge: MIT Press.

Zwart, Jan-Wouter. 1997. The morphosyntax of verb movement: A minimalist approach to Dutch syntax. Kluwer: Dordrecht. 